\title{
Sensitivity of black carbon concentrations and climate impact to aging and scavenging in OsloCTM2-M7
}

\author{
Marianne T. Lund ${ }^{1}$, Terje K. Berntsen ${ }^{1,2}$, and Bjørn H. Samset ${ }^{1}$ \\ ${ }^{1}$ CICERO - Center for International Climate Research, Oslo, Norway \\ ${ }^{2}$ Department of Geosciences, University of Oslo, Oslo, Norway \\ Correspondence to: Marianne T. Lund (m.t.lund@cicero.oslo.no)
}

Received: 30 August 2016 - Discussion started: 9 September 2016

Revised: 14 March 2017 - Accepted: 4 April 2017 - Published: 16 May 2017

\begin{abstract}
Accurate representation of black carbon (BC) concentrations in climate models is a key prerequisite for understanding its net climate impact. BC aging and scavenging are treated very differently in current models. Here, we examine the sensitivity of three-dimensional (3-D), temporally resolved $\mathrm{BC}$ concentrations to perturbations to individual model processes in the chemistry transport model OsloCTM2-M7. The main goals are to identify processes related to aerosol aging and scavenging where additional observational constraints may most effectively improve model performance, in particular for $\mathrm{BC}$ vertical profiles, and to give an indication of how model uncertainties in the $\mathrm{BC}$ life cycle propagate into uncertainties in climate impacts. Coupling OsloCTM2 with the microphysical aerosol module M7 allows us to investigate aging processes in more detail than possible with a simpler bulk parameterization. Here we include, for the first time in this model, a treatment of condensation of nitric acid on BC. Using kernels, we also estimate the range of radiative forcing and global surface temperature responses that may result from perturbations to key tunable parameters in the model. We find that $\mathrm{BC}$ concentrations in OsloCTM2-M7 are particularly sensitive to convective scavenging and the inclusion of condensation by nitric acid. The largest changes are found at higher altitudes around the Equator and at low altitudes over the Arctic. Convective scavenging of hydrophobic $\mathrm{BC}$, and the amount of sulfate required for $\mathrm{BC}$ aging, are found to be key parameters, potentially reducing bias against HIAPER Pole-toPole Observations (HIPPO) flight-based measurements by 60 to $90 \%$. Even for extensive tuning, however, the total impact on global-mean surface temperature is estimated to less than $0.04 \mathrm{~K}$. Similar results are found when nitric acid is al-
\end{abstract}

lowed to condense on the $\mathrm{BC}$ aerosols. We conclude, in line with previous studies, that a shorter atmospheric BC lifetime broadly improves the comparison with measurements over the Pacific. However, we also find that the modelmeasurement discrepancies can not be uniquely attributed to uncertainties in a single process or parameter. Model development therefore needs to be focused on improvements to individual processes, supported by a broad range of observational and experimental data, rather than tuning of individual, effective parameters such as the global BC lifetime.

\section{Introduction}

Black carbon (BC) aerosols play an important role in the climate system through several mechanisms including direct absorption of solar radiation (Bond et al., 2013; Myhre et al., 2013), changing surface albedo (Flanner et al., 2009; Warren and Wiscombe, 1980), modification of cloud properties and thermal stability (Koch and Del Genio, 2010; Lohmann and Feichter, 2005) and influence on precipitation and circulation (Bollasina et al., 2014; Wang et al., 2015). The potentially strong climate warming, combined with short atmospheric residence time and harmful health impacts (Anenberg et al., 2012; Aunan et al., 2006; Shindell et al., 2011), has made BC reductions an attractive mitigation measure (AMAP, 2015; Bowerman et al., 2013; EPA, 2012; Grieshop et al., 2009; Kopp and Mauzerall, 2010; UNEP/WMO, 2011).

Modeling atmospheric concentrations of $\mathrm{BC}$ remains challenging. In particular, it has been well documented that the current model ensembles do not accurately reproduce measured BC vertical profiles (e.g., Koch et al., 2009b; Lee et 
al., 2013; Samset et al., 2014; Schwarz et al., 2013; Wang et al., 2014). Additionally, global models often underestimate Arctic BC surface concentrations and fail to capture the seasonal cycle (e.g., Eckhardt et al., 2015; Shindell et al., 2008). Because the radiative forcing (RF) and temperature response to a perturbation in $\mathrm{BC}$ can depend strongly on altitude, such discrepancies propagate to uncertainties in the net BC climate impact. For instance, overestimating highaltitude BC concentrations can result in an overestimation of the subsequent RF (Samset and Myhre, 2011), whereas too low surface concentrations may lead to an underestimation of the temperature response due to the reduced efficacy of BC forcing with altitude (Ban-Weiss et al., 2011; Flanner, 2013; Samset and Myhre, 2015). This in turn poses significant challenges for the design and evaluation of effective BC mitigation strategies. Studies have shown that both modeled global vertical BC profiles and the transport of the aerosols to the Arctic is strongly influenced by the parameterization of scavenging and aging (Allen and Landuyt, 2014; Bourgeois and Bey, 2011; Browse et al., 2012; Fan et al., 2012; Kipling et al., 2016). However, these parameterizations differ considerably between current models. Increasing the understanding of factors controlling the distribution of $\mathrm{BC}$ in different global atmospheric and climate models is therefore essential.

Here we examine the sensitivity of modeled BC concentrations to factors controlling aerosol lifetime in the OsloCTM2 (Sovde et al., 2008) coupled with the aerosol microphysical parameterization M7 (Vignati et al., 2004; hereafter OsloCTM2-M7). The chemical transport model OsloCTM2 has been documented and used in several multimodel aerosol studies (Balkanski et al., 2010; Myhre et al., 2013; Schulz et al., 2006; Shindell et al., 2013; Textor et al., 2007). These studies used a simplified bulk aerosol scheme. Lund and Berntsen (2012) (hereafter LB12) performed the first analysis of BC simulated by the M7 in the OsloCTM2 and compared results with those from the bulk parameterization. A basic evaluation against selected measurements was performed, showing that using M7 improved the representation of Arctic surface concentrations compared with the bulk scheme, but exacerbated the overestimation of high-altitude BC.

Building on the findings in LB12, we perform a range of sensitivity experiments varying key assumptions in the treatment of aging and scavenging in OsloCTM2-M7 and investigate the resulting range in vertical $\mathrm{BC}$ profiles, as well as high-latitude surface concentrations. Using updated emission inventories, 3 years of model results and observations from surface stations, flight campaigns and snow samples, we also perform a more thorough documentation of the current model performance. Our experiments include a first step towards accounting for $\mathrm{BC}$ aging by gas-phase nitric acid condensation. Measurements have shown that nitrate is frequently present in internal aerosol mixtures (Pratt and Prather, 2010; Shiraiwa et al., 2007). Aging through interaction with nitrate may also become more important in the future following strong projected decreases in $\mathrm{SO}_{2}$ emissions and increasing NOx and greenhouse gas emissions (Bauer et al., 2007; Bellouin et al., 2011; Makkonen et al., 2012), but has so far not been accounted for in our model. We also take the analysis one step further and estimate the range in global RF and surface temperature resulting from the changes in the model parameters. The model setup and experiments are described in Sect. 2, results are presented and discussed in Sect. 3 and conclusions are given in Sect. 4.

\section{Methodology}

\subsection{The OsloCTM2-M7}

The OsloCTM2 is a global offline three-dimensional (3-D) chemistry transport model with transport driven by meteorological data generated by the Integrated Forecast System model at the European Center for Medium Range Weather Forecast (ECMWF) (Sovde et al., 2008). The model is run for 2008-2010 with a T42 resolution (approximately $2.8^{\circ} \times 2.8^{\circ}$ ) and 60 vertical layers from the surface to $0.1 \mathrm{hPa}$.

The microphysical aerosol module M7 (Vignati et al., 2004) includes sea salt, mineral dust, sulfate and organic carbon, in addition to BC. Aerosols are represented by seven modes with size distribution given by a lognormal distribution function. BC exists in the Aitken soluble (mixed) and insoluble mode, soluble accumulation and soluble coarse modes. All BC is emitted in the insoluble Aitken mode. Aging and growth subsequently occurs due to condensation of sulfuric acid produced in the gas-phase oxidation of $\mathrm{SO}_{2}$ by $\mathrm{OH}$ and coagulation with soluble particles. See LB12 for additional details.

Wet deposition in OsloCTM2-M7 is calculated based on ECMWF data for convective activity, cloud fraction and rain fall, and on the solubility of individual species. Removal in large-scale cloud systems follow the scheme by Berge (1993). The parameterization of deep convection is based on the Tiedtke mass flux scheme (Tiedtke, 1989), with mass redistributed in the vertical by a "elevator" principle, i.e., surplus or deficit of mass in the column (Berglen et al., 2004). BC particles in the soluble modes are assumed to be hygroscopic and are removed according to the fraction of the liquid plus ice water content of a cloud that is removed by precipitation (Berntsen et al., 2006). In the baseline setup, $100 \%$ scavenging efficiency (i.e., solubility) by both water and ice in both large-scale and by convective precipitation is assumed. The model does not account for sub-cloud scavenging. Since LB12, the temporal frequency of wet scavenging in OsloCTM2-M7 has been reduced from 3 to $1 \mathrm{~h}$. The OsloCTM2-M7 also keeps track of the BC deposition and concentration in snow; see Appendix A of Skeie et al. (2011) for description. Dry deposition in the OsloCTM2-M7 follows Wesely (1989), with a modification for species in the 
M7 to include size-dependent dry deposition velocities following Seinfeld and Pandis (1998).

The M7 is coupled to the sulfur-oxidant chemistry in OsloCTM2-M7. Nitrate is not included in the baseline M7 setup. However, we perform a sensitivity experiment where gaseous nitric acid is allowed to condense on insoluble BC particles and contribute to aging (Sect. 2.3). The sulfate and nitrate modules in the model are described in detail in Berglen et al. (2004) and Myhre et al. (2006), and we only give brief summaries here.

The sulfur cycle chemistry scheme includes dimethyl sulfide, $\mathrm{SO}_{2}$, sulfate, $\mathrm{H}_{2} \mathrm{~S}$ and methane sulfonic acid and the concentrations of sulfur is calculated interactively with the oxidant chemistry. Sulfate is formed by gas- and aqueousphase oxidation of $\mathrm{SO}_{2}$ by $\mathrm{OH}, \mathrm{H}_{2} \mathrm{O}_{2}, \mathrm{HO}_{2} \mathrm{NO}_{2}$ and $\mathrm{O}_{3}$. When $\mathrm{M} 7$ is used, the gas-phase sulfate is saved in a separate tracer and allowed to condense on the insoluble aerosol modes. The aqueous-phase sulfate is distributed to the accumulation and coarse mode sulfate tracers in M7 according to a prescribed fraction. The treatment of sulfate aerosols then follows M7.

The chemical equilibrium between inorganic species is simulated with the Equilibrium Simplified Aerosol Model (EQSAM; Metzger et al., 2002a, b). EQSAM considers the $\mathrm{NH}_{4}^{+} / \mathrm{Na}^{+} / \mathrm{SO}_{4}^{2-} / \mathrm{NO}_{3}^{-} / \mathrm{Cl}^{-} / \mathrm{H}_{2} \mathrm{O}$ system and the aerosols are assumed to be metastable, internally mixed and obey thermodynamic gas-aerosol equilibrium. Based on the ammonium to sulfate ratio, EQSAM first calculates the preferred state of sulfate. Excess ammonia is available to partition to the aerosol phase, together with gaseous nitric acid, as described in Myhre et al. (2006). Emissions of ammonia are described in Sect. 2.2, while nitric acid is produced through photochemistry as described in Berntsen and Isaksen (1997). The nitrate and ammonium aerosols are represented by two modes, a fine mode comprised of sulfate and a coarse mode comprised of sea salt, and gaseous ammonia and nitric acid can condense on any of these.

\subsection{Emissions}

Anthropogenic emissions for 2008-2010 are from the ECLIPSEv4 inventory (Klimont et al., 2016; available upon request from http://eclipse.nilu.no/). Emissions from international shipping and aviation are from the Representative Concentration Pathway (RCP) 6.0 (Fujino et al., 2006; Hijioka et al., 2008). Biomass burning emissions are from the Global Fire Emission Database version 3 (GFEDv3; van der Werf et al., 2010), biogenic emissions from MEGAN2.1 (Guenther et al., 2012) and natural emissions of ammonia from GEIA (Bouwman et al., 1997). Seasonal variability in domestic emissions is accounted for by using monthly weights (2000-2006 average) for each grid based on spatially distributed temperature data from the Climate Research Unit following the methodology described in Streets et al. (2003), while seasonality in agricultural waste burning is obtained from GFEDv3. Seasonality of emissions in other sectors is not included in ECLIPSEv4. Total BC emissions in 2010 are $5866 \mathrm{Gg}$ from fossil fuel plus biofuel sources and $2273 \mathrm{Gg}$ from biomass burning.

\subsection{Experiments}

We first perform a 3-year base simulation with meteorological data and emissions for 2008-2010, which forms the basis for the model evaluation. Next, we perform a range of sensitivity experiments described in the following paragraphs and summarized in Table 1.

Several sensitivity experiments are related to the aging of BC. First, we explore the impact of varying the amount of soluble material (i.e., sulfate from gas-phase oxidation of $\mathrm{SO}_{2}$ ) required to transfer the $\mathrm{BC}$ aerosols to the soluble mode. The M7 uses the concept of monolayers (ML); when sufficient soluble material is associated with a hydrophobic particle to form " $n$ " monomolecular layers around the particle, the particle is assumed hygroscopic and is transferred to the mixed mode. The amount of soluble material required for a particle to become hygroscopic is an important source of uncertainty (Vignati et al., 2010). Popovicheva et al. (2011) used a laboratory approach to quantify the water uptake by particles with varying amounts of sulfates in order to simulate the aging of combustion particles. Based on a quantification measure for separating hygroscopic and nonhygroscopic soots (Popovicheva et al., 2008), the laboratory results suggest that the transformation of soot particles from hydrophobic to hydrophilic requires an $\mathrm{H}_{2} \mathrm{SO}_{4}$ surface coverage of 0.5-1.4 ML, whereas 1.4-2.3 ML were required for transformation to hygroscopic mode. Based on these results, we perform three model simulations where the ML requirement is changed from 1 in the baseline to $0.5,1.4$ and 2.3. Next, we perform a test where $50 \%$ of $\mathrm{BC}$ from biomass burning sources is emitted directly in the accumulation mode instead of in the insoluble Aitken mode. This is based on observational evidence suggesting that biomass burning BC tends to be larger and more aged, with thicker coatings than BC from urban sources (Schwarz et al., 2008). Finally, we test the impact of allowing for $\mathrm{BC}$ aging by condensation of gas-phase nitric acid. We extend M7, in a simplified manner, to also account for condensation by nitric acid on insoluble particles after gas-aerosol partitioning is calculated in EQSAM. In this experiment, nitric acid contributes only to the transfer of $\mathrm{BC}$ from insoluble to soluble Aitken mode, with no further impact on aerosol size distribution. We follow the same treatment of condensation as for sulfate in M7 (Vignati et al., 2004) and adopt an accommodation coefficient for nitric acid of 0.1 (Pringle et al., 2010). The number of MLs used as the criterion for aging ranges in existing literature. In its original setup, M7 assumes $1 \mathrm{ML}$, based on the best agreement with a sectional model found by Vignati et al. (2004), but this considers sulfate as the only condensable species. Other studies have used a 5 (Pringle et al., 2010) 
Table 1. Summary and description OsloCTM2-M7 experiments performed in this study.

\begin{tabular}{ll}
\hline Experiment & Description \\
\hline Baseline & Standard M7 OsloCTM2 simulation \\
CoatThick0.5 & Required coating thickness reduced to $0.5 \mathrm{ML}$ \\
CoatThick1.4 & Required coating thickness increased to 1.4 ML \\
CoatThick2.3 & Required coating thickness increased to 2.3 ML \\
EmisTest & $50 \%$ of biomass burning BC emitted directly in soluble accumulation mode \\
ConvBCi100 & Hydrophobic BC removed by convective precipitation, 100\% efficiency \\
ConvBCi20 & Hydrophobic BC removed by convective precipitation, 20\% efficiency \\
LSice12 & Scavenging by ice in large-scale precipitation reduced from 100 to 20\% \\
CombPert & LCice12 + ConvBCi20 \\
NitCond & Aging by gas-phase nitric acid condensation included \\
\hline
\end{tabular}

and 10 (Mann et al., 2010) monolayer scheme. Reflecting this range and examining the subsequent impact on concentrations, we here perform three runs assuming 1, 5 and 10 ML.

The second set of sensitivity experiments is related to wet scavenging, the main loss mechanism of $\mathrm{BC}$ and thus a key parameter for the lifetime and distribution. Hydrophilic BC is originally assumed to be $100 \%$ removed by both liquid and ice in large-scale mixed-phase clouds in the OsloCTM2M7. However, this high efficiency of BC removal by icephase precipitation is uncertain. Koch et al. (2009a) found that assuming $12 \%$ ice removal of $\mathrm{BC}$ gave optimal agreement with observations. This fraction was also supported by observations in Cozic et al. (2007) and has been adopted in studies with the OsloCTM2 bulk aerosol parameterization (e.g., Skeie et al., 2011). Here we compare results with 100 and $12 \%$ removal efficiency for large-scale ice-phase clouds. The removal scheme in OsloCTM2-M7 also assumes no wet scavenging of hydrophobic particles. However, hydrophobic $\mathrm{BC}$ aerosol may still be subject to removal by impact scavenging or act as ice nuclei (IN) in convective and mixedphase clouds (Ekman et al., 2006; Kajino et al., 2012; Park et al., 2005). The BC IN activity is not well known. To represent some of this uncertainty, we perform two sensitivity experiments assuming either 100 or $20 \%$ removal efficiency of hydrophobic $\mathrm{BC}$ by convective precipitation, with the latter loosely based on Hoose et al. (2010). We also perform a combination experiment assuming $12 \%$ removal efficiency of hydrophilic BC by large-scale ice-phase clouds and $20 \%$ removal of hydrophobic $\mathrm{BC}$ by convective precipitation.

Finally, we perform two additional tests to investigate the impact of seasonality in emissions and an increase in emissions in Russia following a recent study by Huang et al. (2015). We alternately remove the seasonal variation in domestic and agricultural waste burning emissions and replace ECLIPSEv4 emissions in Russia with the Huang et al. (2015) inventory. These experiments have limited impact on the global $\mathrm{BC}$ distributions, but their influence on the seasonal cycle of Arctic BC concentrations is discussed in Sect. 3.1.1.

\subsection{Radiative forcing and temperature response calculations}

To estimate implications of the concentration changes in our experiments for the global $\mathrm{BC}$ climate impact, we use precalculated RF and surface temperature (TS) kernels derived with the CESM-CAM4 (Samset and Myhre, 2015). These 3$\mathrm{D}$, temporally varying kernels were constructed by systematically applying a uniform $\mathrm{BC}$ burden to one model layer at a time, and calculating the resulting responses. Effective radiative forcing (ERF) was extracted from simulations with prescribed sea-surface temperatures, while temperature responses were taken from simulations with a slab ocean setup. As shown in Samset and Myhre (2015), it is possible to take a perturbation to the 3-D concentration, multiply it with the kernels, and get an estimate for the resulting ERF and temperature change. However, because the $\mathrm{BC}$ perturbations were applied uniformly throughout a single model layer, the temperature response at each grid point will be due to both $\mathrm{BC}$ forcing exerted locally and to forcing in surrounding grid boxes. Combined with the strong altitudinal dependence of forcing and temperature response on the $\mathrm{BC}$ perturbation, we therefore focus on horizontally averaged vertical profiles and not on changes at the grid point level in the present analysis. For each experiment, the globally averaged vertical BC profile from the OsloCTM2-M7 is multiplied with the globally averaged vertical forcing and temperature change kernels. The prior averaging of the profiles has a small impact on the net RF estimates $(<10 \%$, except in two cases where the difference compared to using 3-D kernels is $20 \%$ ) (see also Stjern et al, 2016, for a more comprehensive discussion on this issue). We also estimate the Arctic average forcing and response to Arctic $\mathrm{BC}$ concentrations changes, and briefly investigate the potential uncertainties in Arctic surface temperature using this kernel-based approach due to influence from forcing exerted outside the region. The latter is done by using a kernel for the temperature response caused only by the local Arctic BC perturbation from Flanner (2013) (see Sect. 3.3). The kernels are interpolated to the OsloCTM2M7 resolution before use. Both direct and semi-direct effects 
due to aerosol-radiation interactions are included in the kernel response. In line with the nomenclature of the IPCC Fifth Assessment Report, we hereafter refer to the net effect as ERFari and the direct effect only as RFari.

As discussed by Samset and Myhre (2015), CAM4 does not account for the absorption enhancement due to $\mathrm{BC}$ aging, resulting in a lower RFari per BC burden than earlier studies, especially at higher altitudes (e.g., Samset and Myhre, 2011). The consequent temperature response per unit BC may also be underestimated. However, here we focus on the changes from the baseline in each sensitivity experiment rather than absolute climate impacts.

\subsection{Observations}

Modeled concentrations are evaluated against measurements from surface stations, flight campaigns and snow samples.

Measured surface concentrations of BC, sulfate, nitrate, sulfur dioxide and nitric acid across North America are from the IMPROVE and CASTNET networks, while measurements across Europe and the rest of the world are from the EBAS and NOAA GMD databases. We also use measurements in China from Zhang et al. (2012) and aerosol mass spectrometer campaigns summarized in Zhang et al. (2007).

To evaluate the model performance, we calculate the mean normalized bias (MNB) and root mean square error (RMSE):

$\mathrm{MNB}=\frac{1}{N} \sum\left(\frac{C_{\mathrm{mod}}-C_{\mathrm{obs}}}{C_{\mathrm{obs}}}\right)$,

$\mathrm{RMSE}=\sqrt{\frac{1}{N} \sum\left(C_{\mathrm{mod}}-C_{\mathrm{obs}}\right)^{2}}$

where $\mathrm{C}_{\text {mod }}$ and $\mathrm{C}_{\mathrm{obs}}$ are modeled and observed concentrations and $N$ is the total number of observations.

Following the recommendations by Petzold et al. (2013) observational data are referred to as equivalent $\mathrm{BC}$ (EBC), refractory $\mathrm{BC}(\mathrm{rBC})$ or elemental carbon (EC) depending on whether measurements are derived from optical absorption methods, incandescence methods or methods that specify the carbon content in carbonaceous matter. To convert to $\mathrm{BC}$ concentrations, we adopt a mass-absorption cross section (MAC) of $9.7 \mathrm{~m}^{2} \mathrm{~g}^{-1}$ (Bond and Bergstrom, 2006), except for Alert and Zeppelin, where we use the station-specific MAC reported by Lee et al. (2013).

$\mathrm{BC}$ in snow is compared to snow sample measurements across the Arctic in 2008/2009 (Doherty et al., 2010) and across northern China in 2010 and 2012 (Wang et al., 2013; Ye et al., 2012). In the latter case, model results for 2010 are used.

Vertical profiles of modeled $\mathrm{BC}$ are compared with measurements from several flight campaigns, including ARCPAC (Aerosol, Radiation, and Cloud Processes affecting Arctic Climate), ARCTAS (Arctic Research of the Composition of the Troposphere from Aircraft and Satellites), HIAPER Pole-to-Pole Observations (HIPPO) and A-FORCE (Aerosol
Radiative Forcing in East Asia). During ARCPAC and ARCTAS, flights were made across Alaska and Canadian Arctic in spring and summer of 2008 (Brock et al., 2011; Jacob et al., 2010), while HIPPO measured atmospheric constituents along transects from approximately pole-to-pole over the Pacific Ocean during different seasons from 2009 to 2011 (Wofsy et al., 2011) (see "Data Availability"). The A-FORCE campaign sampled air masses around Japan in March-April 2009 (Oshima et al., 2012) (data kindly provided by Professor Yutaka Kondo, University of Tokyo). Model data are also compared with CO concentrations measured during the campaigns.

Model data are interpolated in time and space and extracted along the flight track. An average profile for each campaign and latitude band is calculated by averaging observations and model results in $100 \mathrm{hPa}$ altitude bins $(25 \mathrm{hPa}$ for HIPPO data between 400 and $200 \mathrm{hPa}$ ). The HIPPO data are also separated into five latitude bands. To evaluate the model performance in each experiment, we calculate the MNB for each campaign following Eq. (1), where $N$ is determined by the number of altitude and latitude bins.

\section{Results and discussion}

\subsection{Model evaluation}

Before examining the impact of our sensitivity experiments on $\mathrm{BC}$ distribution, the baseline performance of the OsloCTM2-M7 must be documented. While the main focus of this paper is $\mathrm{BC}$, the evaluation is extended to include species relevant for the $\mathrm{BC}$ aging process, including sulfate and sulfur dioxide. We also look at the modeled $\mathrm{CO}$ distribution. $\mathrm{CO}$ is another product of incomplete combustion and therefore has many of the same emission sources as BC. However, due to the longer lifetime of $\mathrm{CO}$ a comparison with observations, in particular in the more remote regions mainly influenced by long-range transport, can give an indication of how well the model represents the atmospheric transport.

\subsubsection{Surface concentrations}

On annual mean (year 2008), the OsloCTM2-M7 underestimates BC surface concentrations in Europe, North America and China with an overall MNB of -0.55 (Fig. S1 in the Supplement). The underestimation is largest for measurements in China. The model also underestimates annual mean surface concentrations of sulfate (MNB -0.45), while nitrate concentrations are in better agreement with measurements, with MNB of 0.08 . The overestimation of sulfur dioxide surface concentrations (MNB of 0.70) may be due to too inefficient conversion to sulfate, which is supported by the underestimation of sulfate aerosols, and/or an overestimation of emissions. Also nitric acid concentrations in Europe and North America are overestimated (MNB 0.75). 

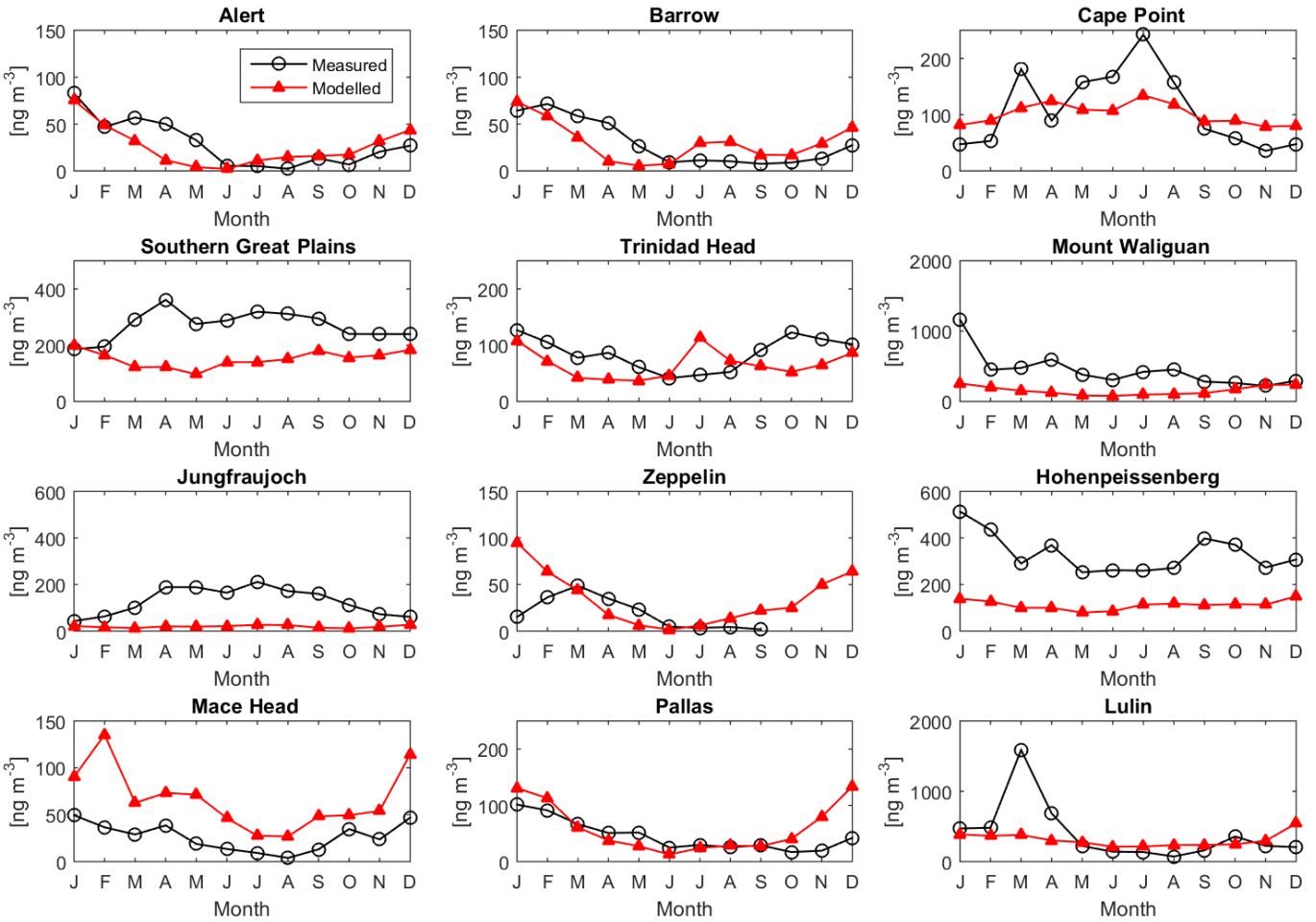

Figure 1. Monthly mean measured EBC versus modeled BC surface concentrations averaged over 2008-2010 (data at Lulin only available for 2009-2010).

Figure 1 shows monthly mean modeled $\mathrm{BC}$ and measured EBC surface concentrations averaged over 2008-2010. The model reproduces the magnitude relatively well at Mace Head, Cape Point, Trinidad Head, Barrow and Pallas, but fail to capture some features in the seasonal variation. Concentrations are also underestimated at Lulin, Hohenpeissenberg and Jungfraujoch during winter and spring.

Studies have found that models often struggle to capture the seasonal cycle and magnitude of measured high-latitude BC surface concentrations (e.g., Eckhardt et al., 2015; Shindell et al., 2008). While there has been considerable progress and several current models capture the seasonality in highlatitude surface concentrations better than previous generations (Breider et al., 2014; Browse et al., 2012; Liu et al., 2011; Sharma et al., 2013), discrepancies remain and there is considerable inter-model variability in simulated Arctic atmospheric BC burdens (Mahmood et al., 2016). This is also the case for the OsloCTM2-M7. LB12 showed that inclusion of aerosol microphysics significantly improved both magnitude and seasonality of Arctic BC. Here we find further improvements by the use of updated emissions, partly due to the inclusion of emissions from flaring, which is an important local Arctic source of BC (Stohl et al., 2013). However, the model still underestimates concentrations during spring. The seasonal variability in emissions is an important factor. Accounting for seasonality in domestic BC emissions in the ECLIPSEv4 inventory increases the burden of total fossil fuel plus biofuel $\mathrm{BC}$ north of $65^{\circ} \mathrm{N}$ by approximately $15 \%$ during winter and by $2 \%$ on annual average compared to assuming constant monthly emissions. Over the same region, including seasonality in agricultural waste burning results in a $2-3 \%$ higher total BC burden during spring. This is a relatively small increase, but agricultural waste burning contributes only around $6 \%$ to total $\mathrm{BC}$ emissions north of $40^{\circ} \mathrm{N}$ on an annual basis. Another potentially important factor is missing or underestimated emission sources. A recent study by Huang et al. (2015) estimated total anthropogenic $\mathrm{BC}$ emissions in Russia of $224 \mathrm{Gg}$, about $40 \%$ higher than in the ECLIPSEv4 inventory. Replacing the ECLIPSEv4 with those from Huang et al. (2015) increases the modeled BC burden north of $65^{\circ} \mathrm{N}$ by about $16 \%$ during fall, winter and early spring and $2-10 \%$ during summer. Another possibly underestimated emission source is open waste burning. Wiedinmyer et al. (2014) used year 2010 population data and estimate that $631 \mathrm{Gg} \mathrm{BC}$ is emitted globally from open waste burning, nearly a factor 7 more than in the ECLIPSEv4 inventory. Moreover, they suggest that open waste burning may contribute $30-50 \%$ to total anthropogenic $\mathrm{PM}_{10}$ emissions in Russia, from where the near-surface transport of $\mathrm{BC}$ to the Arctic is effective (Stohl, 2006). Underestimation of this emission source may thus contribute to the too low modeled Arctic $\mathrm{BC}$ concentrations.

The OsloCTM2-M7 underestimates BC concentrations in snow compared to measurements, particularly in Russia and 
the Canadian Arctic, as has also been seen in previous studies (Lund and Berntsen, 2012; Skeie et al., 2011). In the present analysis, we find higher modeled concentrations than LB12, on the order of $5-15 \mathrm{ng} \mathrm{g}^{-1}$ over large areas north of $70^{\circ} \mathrm{N}$, likely owing to the updated emission inventory and shorter model time step for precipitation. However, this increase is insufficient to compensate for the existing underestimation in the abovementioned regions. The model and measurements agree better for many of the snow samples taken in China.

Eckhardt et al. (2015) showed that models, including the OsloCTM2, have similar difficulties capturing the seasonality in Arctic sulfate concentrations as they have for BC. For instance, the OsloCTM2-M7 underestimates sulfur dioxide during spring at Zeppeling, but overestimates concentrations during summer. Through the aging process, such problems add to the uncertainties in modeled BC.

The model captures measured $\mathrm{CO}$ concentrations in the Northern Hemisphere during summer (Fig. S2), but underestimates the magnitude during winter/spring, a feature that has been shown also for other models in previous studies (Emmons et al., 2015; Monks et al., 2015). In the Southern Hemisphere, the model generally reproduces the magnitude better, with a slight overestimation during winter/spring at several stations. The ability of the model to reproduce the seasonal cycle and magnitude of $\mathrm{CO}$, in particular at remote Southern Hemisphere stations that are mainly influenced by long-range transport, suggests that the model represents atmospheric transport reasonably well and points to other processes as the dominant source of uncertainty in the model.

\subsubsection{Vertical profiles}

Figure 2 shows modeled vertical BC profiles against measurements from aircraft campaigns. Compared to measurements from ARCPAC and ARCTAS spring the OsloCTM2M7 underestimates the magnitude of $\mathrm{BC}$ concentrations throughout the atmosphere (Fig. 2p, r; MNB -0.8). However, the shape of the profile is reproduced reasonably well. During April 2008, when these campaigns were undertaken, there was unusually strong fire activity in Siberia and air masses were heavily influenced by biomass burning emissions (Brock et al., 2011; Jacob et al., 2010; Warneke et al., 2009). During several flights, the biomass burning plumes were specifically targeted. Possible explanations for the strong discrepancies could therefore be underestimation of the fire emissions or inaccurate representation of the plumes in the model. The model also underestimates the magnitude of $\mathrm{CO}$ concentrations during these two campaigns (Fig. S3p, r; MNB -0.3), but again captures the profile shape reasonably well, providing further indication that too low emissions could be an important reason for the discrepancy. The agreement is better for ARCTAS summer (Fig. 2q; MNB 0.05). The majority of flights during the ARCTAS summer campaign took place over Canada, where the fire activity was generally low that year. Moreover, our evaluation against monthly surface concentrations of BC suggest a generally better agreement at high latitudes during summer than spring (Sect. 3.1.1). This is not the case for CO (Fig. S3q; MNB $-0.4)$.

Measurements from HIPPO are separated into five latitude bands (Fig. 2a-o). For most latitude bands and flights, there is reasonable agreement close to the surface. In the 60$80^{\circ} \mathrm{N}$ latitude band, the model overestimates concentrations close to the surface during HIPPO1 and 2, but underestimates concentrations during HIPPO3. HIPPO3 was undertaken during spring and a similar underestimation was also seen in the modeled surface measurements at Barrow during this time of year (Fig. 1). The model typically fail to reproduce the layered structure of the measured vertical profiles. In particular, the high-altitude concentrations in tropics and the southern mid-latitudes are overestimated. It should be noted that there are substantial differences between the three HIPPO campaigns although they all cover the Pacific. A better model-measurement agreement is found for HIPPO3 than for HIPPO1 and 2 (MNB 1.1, 3.3 and 2.8, respectively). In contrast to $\mathrm{BC}$, both the magnitude and shape of most vertical $\mathrm{CO}$ profiles compare well across all latitude bands (Fig. S3ao; MNB 0.1, -0.1, -0.09).

There is quite good agreement between measured and modeled BC during the A-FORCE campaign (Fig. 2s; MNB -0.1 , with model results falling within 1 standard deviation of the measured profile. The A-FORCE campaign was carried out downstream of nearby emission sources and the good agreement with observations suggests reasonable representation in the model of both emission magnitude in the region and the mixing with the free troposphere on timescales of a few days. In contrast, the HIPPO campaigns sampled older air masses, where loss processes have had more time to influence the distribution. The $\mathrm{CO}$ concentrations is underestimated during A-FORCE (Fig. S3s; MNB -0.3).

Our overall findings are in line with other recent studies. The tendency to overestimate high-altitude BC concentrations over the Pacific has been noted for several other model (Kipling et al., 2013; Samset et al., 2014; Schwarz et al., 2013; Wang et al., 2014). The vertical profiles from OsloCTM2-M7 also fall roughly within the range of the AeroCom Phase II models (Samset et al., 2014).

\subsection{Sensitivity of BC concentrations to changes in aging and scavenging}

Next we discuss the changes in modeled BC concentrations in our experiments, and examine the resulting range in vertical profiles and Arctic surface concentrations.

Table 2 summarizes the global BC burden and lifetime in each experiment. The global-mean burden (lifetime) is $133 \mathrm{Gg}$ (6 days) in the base simulation, while there is considerable range from $81 \mathrm{Gg}$ (3.6 days) to about $185 \mathrm{Gg}$ ( 8 days) across the experiments. The largest changes result from increasing the number of MLs required for ag- 

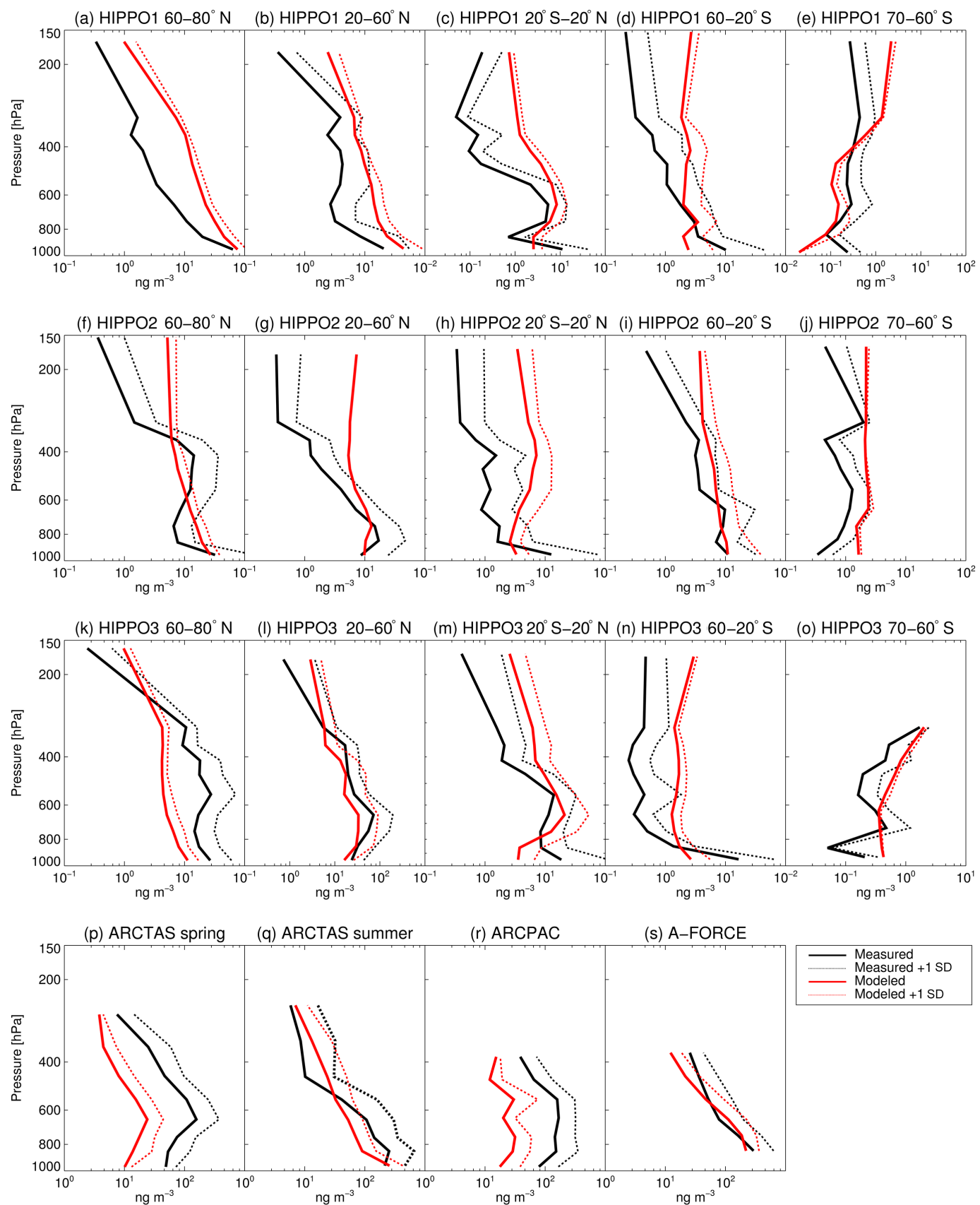

Figure 2. Comparison of modeled vertical BC profiles with measured rBC from six flight campaigns: (a-o) HIPPO 1-3, averaged over five latitude bands, (p-q) ARCTAS, spring and summer, (r) ARCPAC and (s) A-FORCE. Solid lines show the average of observations and model results binned in $100 \mathrm{hPa}$ intervals ( $25 \mathrm{hPa}$ for HIPPO data between 400 and $200 \mathrm{hPa}$ ), while dashed lines show the standard deviation in each interval.

ing (CoatThick2.3), allowing convective scavenging of hydrophobic $\mathrm{BC}(\mathrm{ConvBCi})$ and including aging by nitric acid (NitCond). The range of $\mathrm{BC}$ lifetimes still falls within that of estimates from different global models (e.g., Samset et al., 2014).

To examine the impacts in more detail, we calculate the differences in zonal mean concentration (Fig. 3) and bur- den (Fig. S5) between each experiment and the baseline. Figure $\mathrm{S} 4$ shows the zonal mean concentration in the baseline simulation. The changes follow a similar spatial distribution in most experiments, with largest changes in the lower model layers north of $60^{\circ} \mathrm{N}$ and around the equatorial Atlantic. The changes in concentrations north of $60^{\circ} \mathrm{N}$ are largely determined by changes in the potential for long-range 

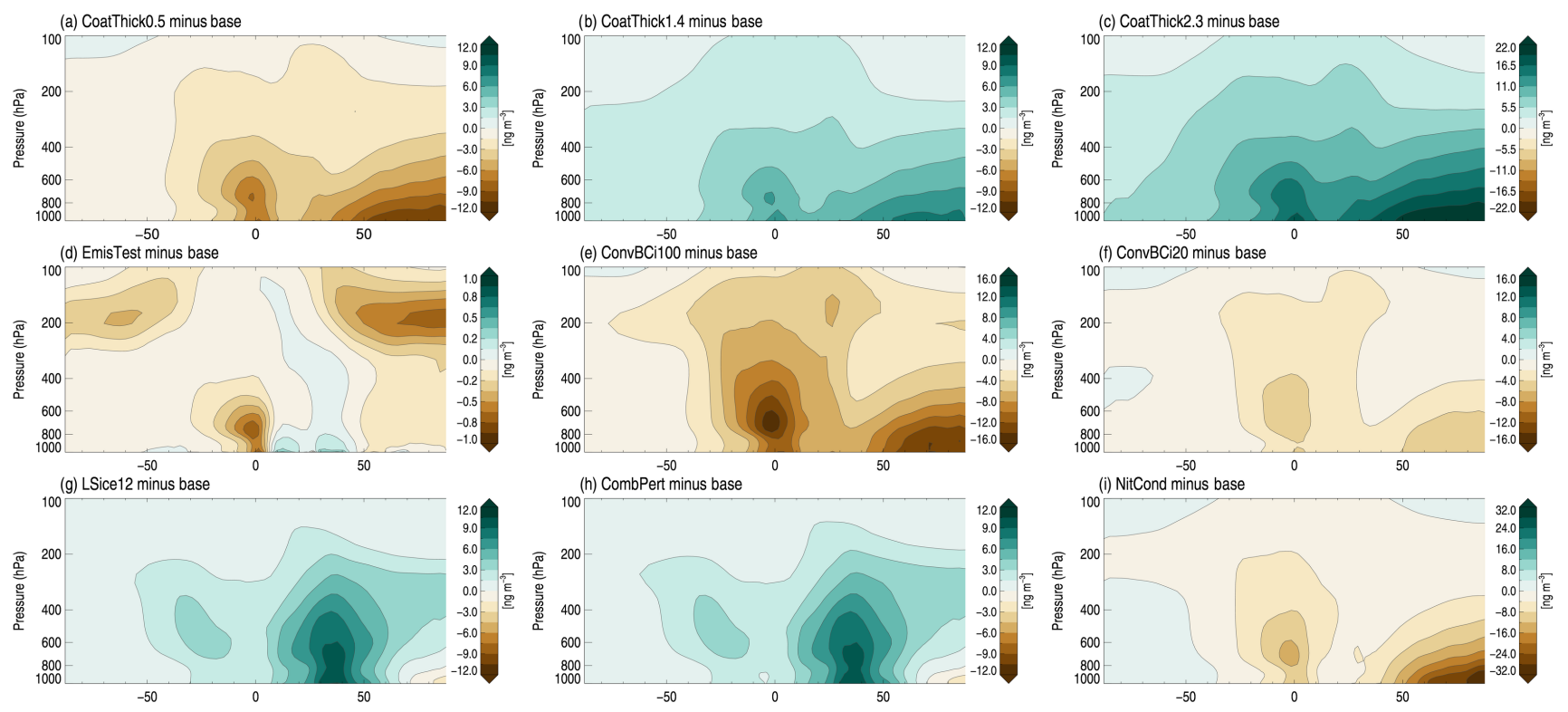

Figure 3. Difference in zonal, annual mean burden between each sensitivity experiment and the baseline simulation.

Table 2. Global BC lifetime and burden in each experiment.

\begin{tabular}{lrr}
\hline & $\begin{array}{r}\text { Lifetime } \\
{[\text { days] }}\end{array}$ & $\begin{array}{r}\text { Burden } \\
{[\mathrm{Gg}]}\end{array}$ \\
\hline Base & 6.0 & 133 \\
CoatThick0.5 & 4.8 & 106 \\
CoatThick1.4 & 6.7 & 150 \\
CoatThick2.3 & 8.3 & 185 \\
EmisTest & 5.9 & 131 \\
ConvBCi100 & 3.6 & 81 \\
ConvBCi20 & 4.8 & 107 \\
LSice12 & 6.6 & 147 \\
Combpert & 6.6 & 148 \\
NitCond & 3.9 & 87 \\
\hline
\end{tabular}

transport of BC from the Northern Hemisphere source regions with decreasing or increasing lifetime. The pronounced maxima over the equatorial Atlantic coincides with the outflow region with frequent precipitation from areas with high biomass burning activity, where changes in aging rate or lifetime strongly influences the amount that is removed by wet scavenging. In contrast to the other experiments, assuming that more biomass burning $\mathrm{BC}$ is emitted directly in the accumulation mode only has a very small effect on concentrations (Fig. 3d). Asia is also an important BC source region; however, the absolute changes are smaller here than around the Equator. In the coating thickness experiments (Fig. 3ac), one possible explanation contributing to the differences could be sulfate levels, with higher concentrations available for coating of the $\mathrm{BC}$ particles, and thus lower sensitivity to changes in the aging requirement, in Asia.
Allowing for convective scavenging of hydrophobic BC results in considerable high-altitude changes, in particular over the tropics where convective activity is strong (Fig. 3e, f). The maximum change in concentrations is shifted to northern mid-latitudes in the experiments when the largescale ice-scavenging efficiency of hydrophilic BC is reduced (Fig. 3g, h), with the largest absolute changes over eastern Asia (Fig. S5g, h). An increase in this region could reduce the general underestimation of surface concentrations found in the base simulation (Fig. S1). These experiments illustrate that the modeled concentrations are sensitive to the fractions of $\mathrm{BC}$ available for scavenging. For convective scavenging of hydrophobic aerosols, we assume either 20 or $100 \%$ to represent a wide range. However, the solubility and IN efficiency of $\mathrm{BC}$ are uncertain parameters poorly constrained by observations.

The strong sensitivity of concentrations at high northern latitudes and around the tropics to changes in the convective scavenging of hydrophobic BC and inclusion of aging by nitric acid may seem surprising given that measurement suggest that significant the majority of freshly emitted hydrophobic BC particles quickly acquire coatings and become internally mixed (Gong et al., 2016; McMeeking et al., 2011; Moteki et al., 2007). Consequently, externally mixed BC particles are likely rare in the remote atmosphere. However, there is still little information about the aerosol mixing state in aged air masses, especially at high latitudes (Raatikainen et al., 2015). In the baseline OsloCTM2-M7, a considerable fraction of total $\mathrm{BC}$ is in the insoluble Aitken mode (BCi) $(45 \%$, or $60 \mathrm{Gg}$, of the global BC burden with an aging timescale of 2.7 days). In particular, $\mathrm{BCi}$ constitutes the dominating fraction of total annual mean $\mathrm{BC}$ concentration 

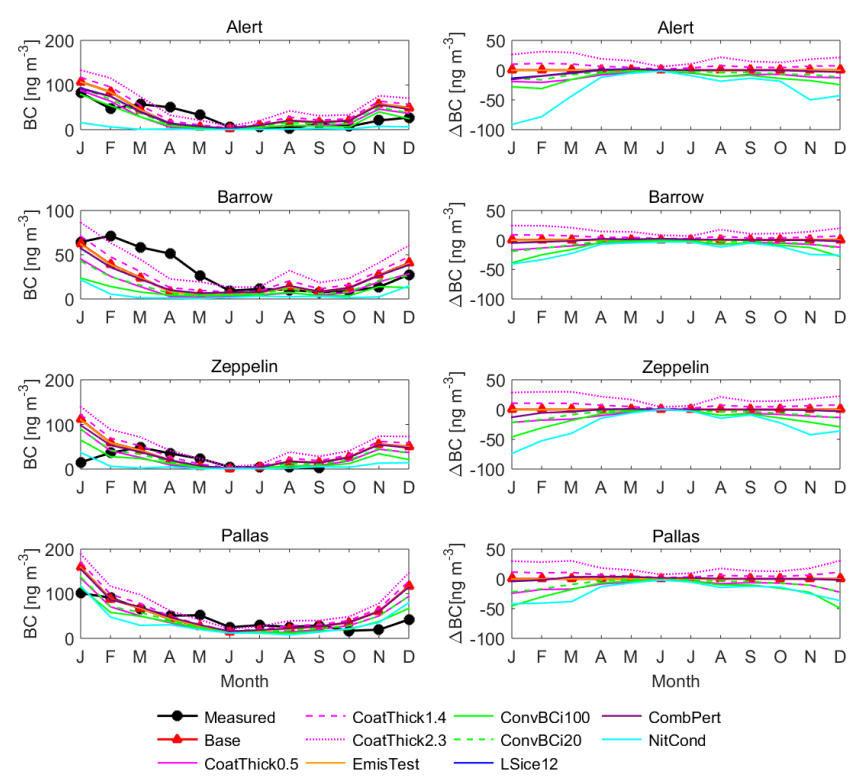

Figure 4. Monthly surface concentrations of $\mathrm{BC}$ at Arctic stations in 2008: (right) measurements versus baseline and sensitivity experiments and (left) difference between each sensitivity experiment and the baseline.

north and south of $60^{\circ}$ (Fig. S4b). However, there are important seasonal variations, and high-latitude BCi concentration is highest during winter, when the aging is slower due to less efficient production of sulfate. Convective scavenging can be an important loss mechanism during Arctic winter, resulting in a considerable reduction in $\mathrm{BC}$ concentrations in the ConvBCi experiment. BCi also dominates above $300 \mathrm{hPa}$ around the tropics.

The largest changes in concentration results from inclusion of condensation of nitric acid (Figs. 3i, S5i). The number of MLs assumed as the criterion for aging is a key parameter. Different values have been assumed in studies with different aerosol schemes. Here we test the range of results under varying MLs in the same model (Fig. S6). The resulting global burden and lifetime is approximately $40 \%$ higher in the simulation assuming $10 \mathrm{MLs}$ than with $1 \mathrm{ML}$. The largest differences are found over southern and eastern Asia. With no firm agreement on the most correct number to use, we focus on results from the simulation with the middle value of 5 MLs in the following paragraphs.

Next, we examine the impact of the changes in concentrations on the existing model-measurement discrepancies. We focus on the Arctic stations (Alert, Barrow, Pallas and Zeppelin), as well as the vertical profiles from the aircraft campaigns discussed in Sect. 3.1.2. Figure 4 shows seasonal Arctic surface concentrations compared to the measurements (left column) and the absolute difference from the base in each experiment (right column). Figure 5 shows the vertical $\mathrm{BC}$ profiles for each campaign and experiment, compared to the baseline and measurements.
A shorter atmospheric BC lifetime reduces the highaltitude overestimation at mid- and tropical latitudes over the Pacific. This is in line with other recent studies showing that modeled BC vertical profiles agree better with HIPPO data, in particular at higher altitudes, when the global BC lifetime is reduced (Hodnebrog et al., 2014; Samset et al., 2014; Wang et al., 2014). The MNB for the HIPPO campaigns is substantially reduced in the ConvBCi and CoatThick0.5 experiments compared to the baseline (from approx. 3 to -0.3 and 1 , respectively). In most latitude bands, the reduction in MNB is largest for the former of the two. Given that the largest concentration changes in most of the experiments in the present analysis are found over the equatorial Atlantic (Fig. S5), a future comparison of our results against vertical profiles from the ongoing ATom campaign (http: //espo.nasa.gov/home/atom/content/ATom) will be a useful exercise. Our results are supported by Kipling et al. (2016), who also found convective scavenging to be an important parameter for the global vertical BC profile in the HadGEM3UKCA. Surface concentrations at Alert, Zeppelin and Pallas are also reproduced reasonably well in these experiments, although the springtime underestimation discussed above remains. In other parts of the Arctic, however, the model performance is exacerbated. More specifically, the MNB for the ARCTAS and ARCPAC campaigns increases, and the underestimation of surface concentration at Barrow is larger compared to the baseline. Similar effects are also found in the $60-70^{\circ} \mathrm{S}$ region (Fig. 5e, j). Several other factors not considered here could also contribute to the too low modeled Arctic concentrations, including uncertainties in emissions and model resolution. For instance, a recently published study point to the importance of model resolution as a source of uncertainty, suggesting that a kilometer-order resolution is required for more accurate representation of $\mathrm{BC}$ concentrations in the Arctic (Sato et al., 2016).

Conversely, increasing the amount of soluble material required for aging increases the BC lifetime. This in turn results in an increased potential for long-range transport and increase in Arctic surface concentrations. However, with the exception of Barrow during spring, increasing the number of required ML (CoatThick1.4, CoatThick2.3) does not result in marked improvements in modeled Arctic surface concentrations compared to measurements. The modeled seasonal cycle in Arctic concentrations changes very little in all experiments. The longer aging time in CoatThick1.4 and CoatThick2.3 also results in a poorer agreement with the HIPPO measurements, both close to the surface and at high altitudes. Moreover, even with the longer lifetime and consequent increases in Arctic BC concentrations, the model does not reproduce the vertical profiles from ARCTAS and ARCPAC. These experiments also result in reduced concentrations of $\mathrm{BC}$ in snow in our model, since more $\mathrm{BC}$ resides in the insoluble mode, unavailable for wet scavenging. Hence, in the OsloCTM2-M7 a slower BC aging alone does not significant improve any model-measurement discrepancies. 

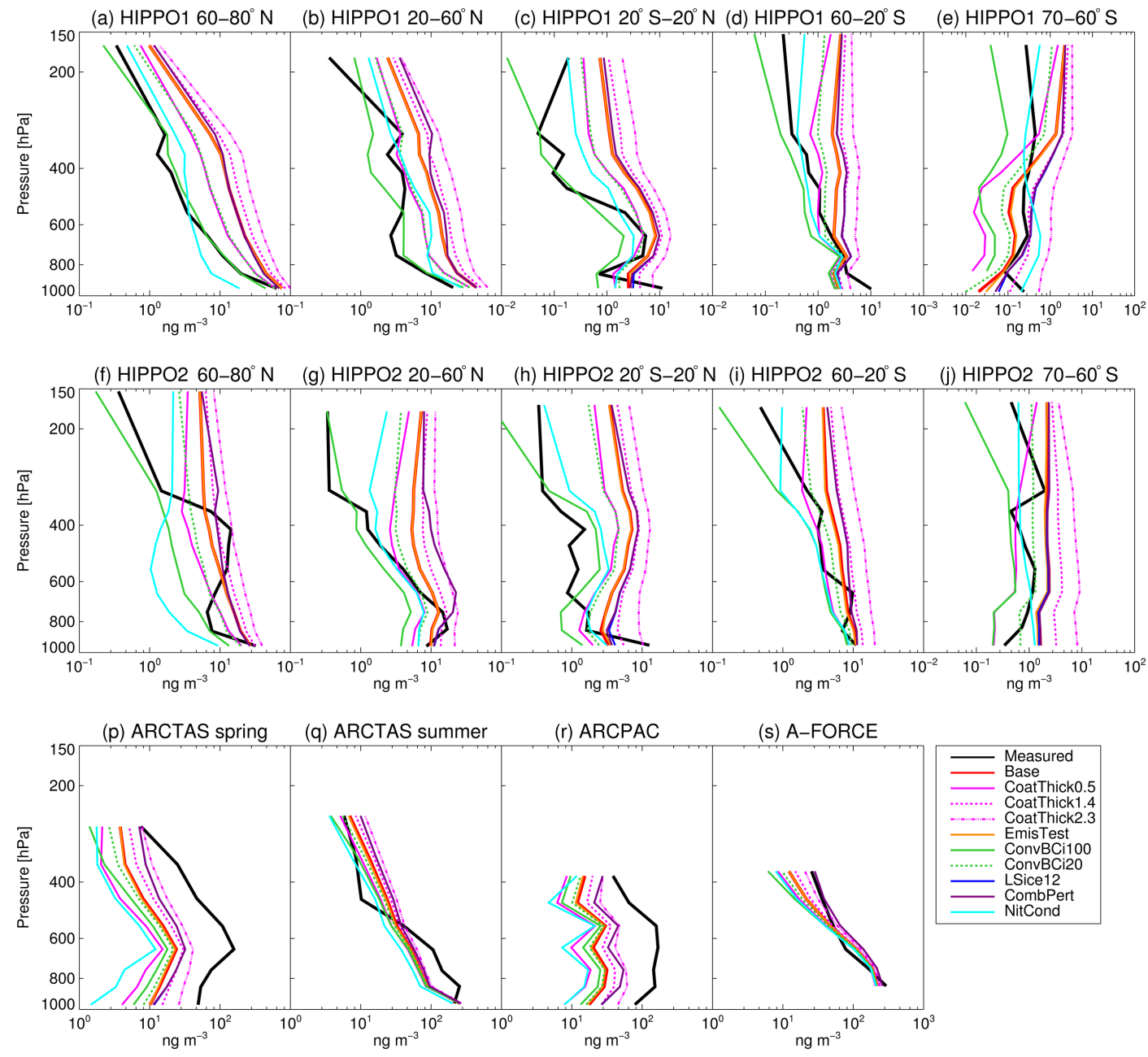

Figure 5. Vertical BC profiles in the baseline and sensitivity experiments compared to flight campaigns.

Reducing the scavenging of $\mathrm{BC}$ by large-scale ice clouds and increasing the fraction of biomass burning emissions initially in the accumulation mode, have only a minor influence on the comparison with both Arctic surface concentrations and HIPPO profiles. The smaller impact in the former experiment contrasts the results by Fan et al. (2012), who found a good agreement with HIPPO data when reducing the removal efficiency of hydrophilic BC by snow in their model. However, Fan et al. (2012) used a more detailed treatment of large-scale ice precipitation and adopted even lower scavenging coefficients than in our analysis.

Measurements at mid-latitudes have shown that nitrate is frequently present in internal aerosol mixtures and contribute to the aging of BC (Pratt and Prather, 2010; Shiraiwa et al., 2007). The addition of $B C$ aging by nitric acid is a new development in the OsloCTM2-M7 and results from this experiment are discussed separately here. Allowing for nitric acid to condense on the aerosols results in a faster aging as more soluble material is available and hence reduces the global
$\mathrm{BC}$ lifetime. This in turn reduces high-altitude $\mathrm{BC}$ concentrations and the discrepancies in the HIPPO comparison (MNB 0.4 and 0.7 for HIPPO1 and HIPPO2, respectively). Furthermore, $\mathrm{BC}$ snow concentrations across all regions except Greenland increase in this experiment, although not enough to fully account for the existing underestimation compared to measurements. However, the Arctic atmospheric BC concentrations are reduced, resulting in a poorer model performance compared to both measured vertical profiles and surface concentrations in this region. The work in this study is a first step and tests the potential importance of accounting for nitrate in the aerosol microphysics parameterization. There are, however, important limitations. For instance, the current setup only treats the condensation by nitric acid, not coagulation with nitrate aerosols. Another important caveat is that we do not account for changes in hydrophilicity resulting from evaporation of nitric acid already condensed on the aerosols. This may result in an overestimation of the contribution from nitric acid to the aging, at least in certain regions. In addition 
to nitrate, condensation of organic aerosols could play an important role in the aging of BC. For instance, He et al. (2016) recently found that a microphysics-based $\mathrm{BC}$ aging scheme including condensation of both nitric acid and secondary organics resulted in improved representation of BC in GEOSChem compared with HIPPO measurements. This process is currently not included in the OsloCTM2-M7, but should be addressed in future work.

Our analysis does not consider combinations of or regionally differing sensitivity experiments, for instance increased coating thickness required at high latitudes in combination with more efficient removal by convective precipitation in low and mid-latitudes. Moreover, there are important details that are not captured in the OsloCTM2-M7. For example, the OsloCTM2-M7 assumes that particles can automatically act as cloud condensation nuclei once they are transferred from the hydrophobic to hydrophilic mode. However, the cloud condensation activity of hydrophilic and hygroscopic particles also depends on the atmospheric supersaturation (Koehler et al., 2009; Petters and Kreidenweis, 2007). Furthermore, particles may not merely be hydrophilic or not, as assumed by models, but can exhibit degrees of hydrophilicity. Our results underline the importance of more observations, in particular of the mixing state and scavenging of $\mathrm{BC}$, as well as experimental data, to improve process understanding.

\subsection{Climate impacts}

As input to the discussion around the role of $\mathrm{BC}$ as a climate forcer, the impact of the changes in model parameters on RF and TS is estimated using the kernel-based approach described in Sect. 2.4.

Figure 6 shows the change in BC ERFari (i.e., net of direct and semi-direct aerosol-radiation interactions), RFari (i.e., direct aerosol effect only) and TS in each experiment. Relative to the baseline, decreases in global-mean BC RFari up to $-180 \mathrm{~mW} \mathrm{~m}^{-2}$ are estimated for the two experiments that lead to the most marked improvements (i.e., strongest reduction in MNB) in vertical profiles compared to measurements over the Pacific (ConvBCi and NitCond) (Fig. 6). A notable decrease in RFari of $-90 \mathrm{~mW} \mathrm{~m}^{-2}$ is also estimated for the CoatThick 0.5 experiment. These changes are on the order of $25-50 \%$ of the RFari in the baseline simulation, estimated to be $0.35 \mathrm{~W} \mathrm{~m}^{-2}$. The Fifth IPCC Assessment Report reports a best estimate of RFari (relative to pre-industrial) due to BC from all sources of $0.6 \mathrm{~W} \mathrm{~m}^{-2}$ (Boucher et al., 2013), while Bond et al. (2013) give a slightly higher estimate of $0.71 \mathrm{~W} \mathrm{~m}^{-2}$. Hence, the changes in our sensitivity experiments are up to $30 \%$ of the total best estimate of BC RFari relative to pre-industrial. We emphasize that the RFari from the baseline simulation in the present study should not be compared with estimates of pre-industrial to present forcing by $\mathrm{BC}$ as it does not include the absorption enhancement due to $\mathrm{BC}$ aging and is given relative to a no- $\mathrm{BC}$ situation.
Including the semi-direct aerosol impacts partly offsets the RFari. The decrease in global-mean BC ERFari is $-49,-45$ and $-26 \mathrm{~mW} \mathrm{~m}^{-2}$ in the ConvBCi, NitCond and CoatThick0.5 experiments. Changes in ERFari of similar magnitudes but opposite sign are estimated for the CoatThick 1.4 and CoatThick 2.3 experiments. The change in TS is also largest for three former experiments, resulting in a decrease of -14 to $-25 \mathrm{mK}$ compared to the baseline (13$22 \%$ of the TS in the baseline simulation estimated using the kernel-based approach).

Both forcing and temperature response is sensitive to the altitude of $\mathrm{BC}$ concentration change. Figure 7 examines the vertical variability behind results in Fig. 6 . The globally averaged ERFari (Fig. 7b) peaks below $900 \mathrm{hPa}$ and around $200 \mathrm{hPa}$, driven by contributions from both the semi-direct and direct radiative effects. The direct radiative effect per BC burden increases with altitude (see also Fig. 1 of Samset and Myhre, 2015), resulting in a larger change in RFari at higher altitudes in the present analysis, especially in the ConvBCi and NitCond experiments (Fig. 7a). In contrast, the semidirect effect per BC burden is positive below $900 \mathrm{hPa}$, but negative and increasing in strength at higher altitudes. Between 800 and $400 \mathrm{hPa}$ the ERFari is smaller due to canceling direct and semi-direct effects. The net changes in ERFari in Fig. 6 are thus largely determined by an RFari contribution due high-altitude concentration changes in our experiments and a low-altitude contribution from the semi-direct effect. The TS change is largest in the lower models layers (Fig. 7c), in agreement with the decreasing efficacy of $\mathrm{BC}$ forcing with altitude.

We also estimate the changes in Arctic ERFari and TS (not shown here). These are generally larger than the global-mean changes. In the CoatThick and NitCond experiments, we estimate $30-50 \%$ higher change in ERFari due to Arctic BC concentration changes compared to the global-mean change. This reflects that the concentration changes are larger in the lower model layers at high northern latitudes in these experiments (Fig. 3), combined with a stronger direct radiative efficiency over this region and a relatively smaller semi-direct effect, which offsets less of the RFari than globally averaged. Surface temperature response per BC burden is also larger for low-altitude perturbations at high latitudes than globally averaged, and even becomes slightly negative, i.e., a cooling, above $400 \mathrm{hPa}$ north of $70^{\circ} \mathrm{N}$. The low-altitude concentration changes in Arctic therefore also results in larger TS changes (by a factor 2-4) compared to the global-mean change.

There is, however, an important caveat when using the temperature kernel from Samset and Myhre (2015) to estimate Arctic changes. Because globally uniform BC perturbations were imposed in each model layer, the impact on temperature in a specific grid box may be due both to forcing exerted locally and to remote forcing through large-scale circulation impacts. To exclude any possible influence of $\mathrm{BC}$ forcing exerted outside the Arctic region, we also use results from Flanner (2013) to estimate the change in Arctic 


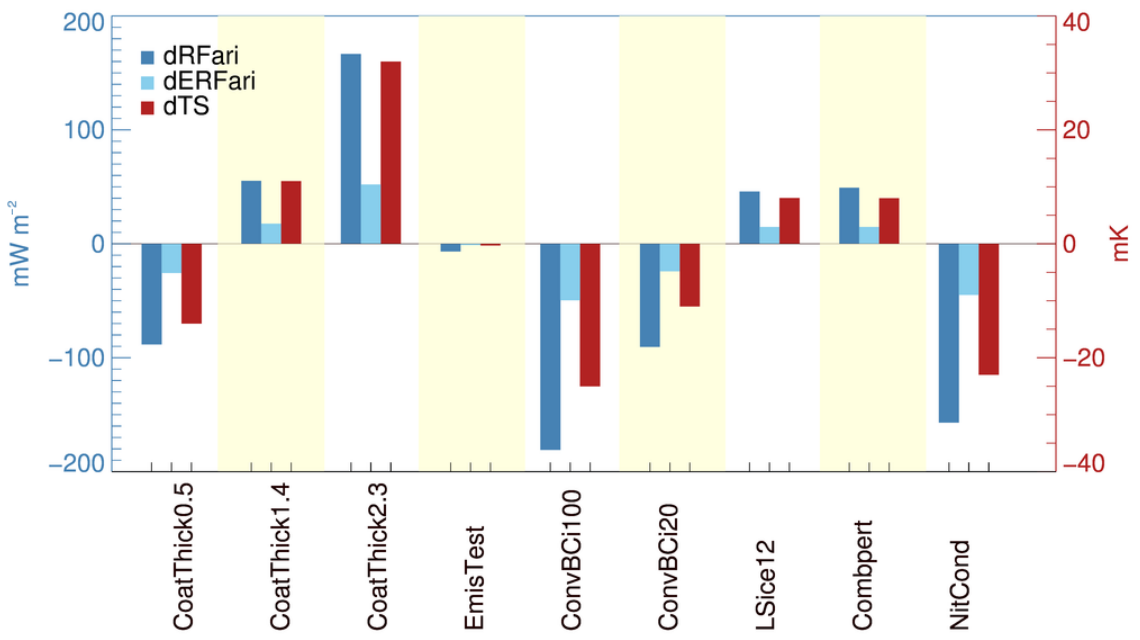

Figure 6. Net change in RFari, ERFari and TS between each sensitivity experiment and the base simulation, estimated using the kernels from (Samset and Myhre, 2015).

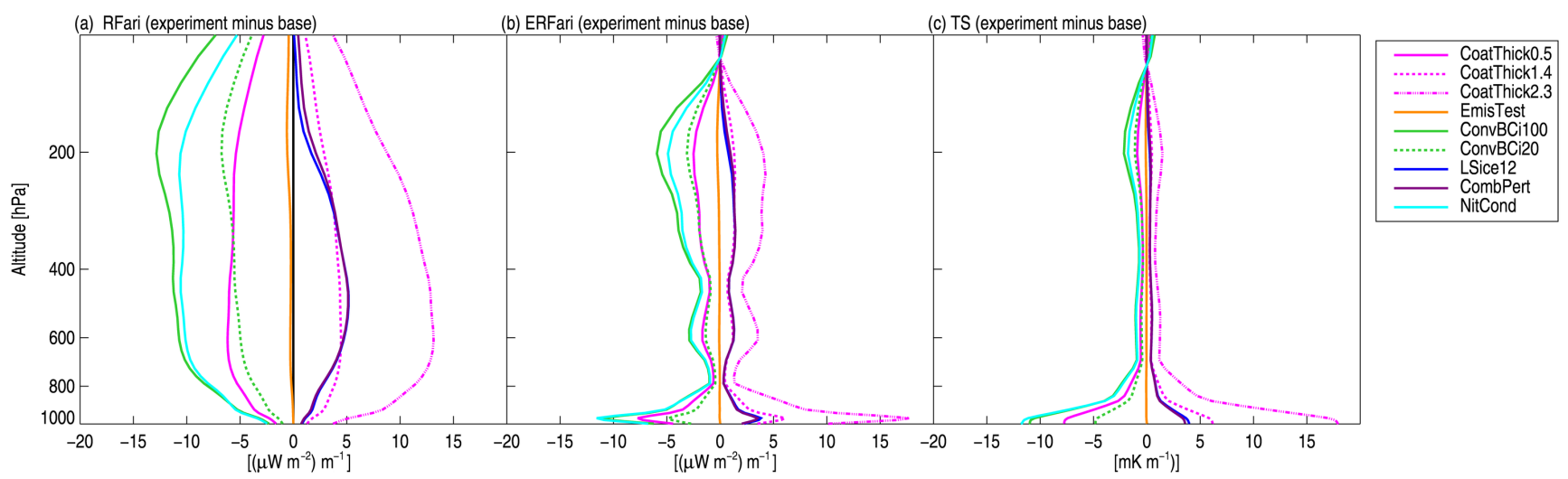

Figure 7. Change in (a) RFari, (b) ERFari and (c) TS between each sensitivity experiment and the base simulation as a function of altitude.

TS. Flanner (2013) imposed BC perturbations at five different altitudes over the Arctic only, using the same model as Samset and Myhre (2015), hence calculating the Arctic TS caused only by a local perturbation. The resulting temperature kernel has previously been used to assess the impact of regional on-road diesel BC emissions (Lund et al., 2014). When used here to estimate the impact of our experiments, we find similar changes in Arctic TS to those estimated using results from Samset and Myhre (2015), with some small differences. In the LSice 12 and CombPert experiments, the changes in net Arctic TS estimated using Flanner (2013) are of opposite sign from results using the kernel from Samset and Myhre (2015). This is caused by different efficacies above $500 \mathrm{hPa}$, where these experiments give the largest changes in Arctic BC concentrations.

\section{Summary and conclusions}

We have performed a range of experiments to investigate the sensitivity of BC concentrations modeled by the OsloCTM2M7 to parameters controlling the aerosol scavenging and aging, including, for the first time in the model, a treatment of condensation of nitric acid on BC particles. The impact of changes in these processes on the existing modelmeasurement discrepancies in Arctic surface concentrations and high-altitude concentrations over remote regions of the Pacific is investigated, in order to identify potential improvements to be included in future work. Our analysis is further extended to include an assessment of the effect of the concentration changes on subsequent radiative forcing and surface temperature response.

We find changes of up to $40 \%$ in global $\mathrm{BC}$ burden and lifetime compared to the baseline, with the largest decreases resulting from inclusion of convective scavenging of hydrophobic $\mathrm{BC}$ and aging by nitric acid condensation. In most 
experiments, the largest changes in concentrations are found in lower model layers north of $60^{\circ} \mathrm{N}$ and at higher altitudes around the equatorial Atlantic. In the experiments with the most pronounced $\mathrm{BC}$ concentration changes relative to the baseline, we calculate changes in global-mean RFari (i.e., direct RF) on the order of $10-30 \%$ of the total pre-industrial to present $\mathrm{BC}$ direct forcing. However, even with the considerable changes in concentrations, the total impact (i.e., net of direct and semi-direct aerosol-radiation interactions) on global-mean surface temperature is estimated to less than $0.04 \mathrm{~K}$.

A shorter atmospheric BC lifetime in the OsloCTM2-M7 reduces the high-altitude overestimation at mid- and tropical latitudes over the Pacific and improves the comparison with HIPPO measurement data, providing further support to findings from recent studies (Hodnebrog et al., 2014; Samset et al., 2014; Wang et al., 2014). However, this required shorter lifetime can be achieved through changes in several different model parameters. Both inclusion of convective scavenging of hydrophobic $\mathrm{BC}$ and reduction in the amount of soluble material required for $\mathrm{BC}$ aging results in a 60 to $90 \%$ lower MNB in comparison with vertical profiles from HIPPO, relative to the baseline. In the case of convective scavenging, the model is sensitive to the fraction of hydrophobic BC assumed to be available for removal, which is a poorly constrained parameter. The OsloCTM2-M7 is better able to reproduce the observed seasonal variation and magnitude of Arctic BC surface concentrations compared to previous OsloCTM2 studies, although model-measurement discrepancies remain, particularly during spring. Surface concentrations at Alert, Zeppelin and Pallas remain in reasonable agreement with observations in the two abovementioned experiments, but the agreement with measurements at Barrow becomes poorer.

We also find similar improvements in the comparison with HIPPO measurements when including BC aging by condensation of nitric acid. However, the Arctic atmospheric $\mathrm{BC}$ concentrations are substantially reduced, resulting in a poorer model performance compared to both measured vertical profiles and surface concentrations in the region. The treatment of $\mathrm{BC}$ aging by nitric acid included here is a first step. Further work to resolve uncertainties and incorporate missing processes, such as coagulation with nitrate aerosols and secondary organics, is needed for the development of a more comprehensive aerosol microphysical parameterization in the OsloCTM2-M7.

The existing model-measurement discrepancies in the OsloCTM2-M7 can not be uniquely attributed to uncertainties in a single process or parameter. Furthermore, improvements compared to measurements in one geographical region can be accompanied by a poorer model performance in other. This underlines the need for better process understanding supported by observational and experimental data, e.g., of BC IN efficiency, aging rate and mixing state, rather than tuning of individual, effective parameters such as global $\mathrm{BC}$ lifetime, to further improve models and constrain esti- mates of BC climate impact. Sensitivity studies may therefore provide important insight ahead of upcoming measurement campaigns regarding where experimental efforts could be focused in order to provide the best possible data for further constraining global models.

Data availability. Observational data used in this study are collected from the following publicly available databases: the EBAS database (http://ebas.nilu.no/; NILU, 2015) hosted by NILU - Norwegian Institute for Air Research. NOAA ESRL Global Monitoring Division, available at https://www.esrl.noaa.gov/gmd/ (NOAA, 2013). The US national clean air status and trends monitoring network CASTNET, available at http://www.epa.gov/castnet (U.S. Environmental Protection Agency Clean Air Markets Division, 2015). The Interagency Monitoring of Protected Visual Environments (IMPROVE), a collaborative association of state, tribal, and federal agencies, and international partners, with the US EPA as the primary funding source and support from the $\mathrm{Na}$ tional Park Service. Data available at http://views.cira.colostate. edu/fed/DataWizard/Default.aspx (FED, 2013). Data from the flight campaigns ARCTAS, ARCPAC and HIPPO are available online at http://www.esrl.noaa.gov/csd/projects/arcpac/, https://www-air. larc.nasa.gov/missions/arctas/arctas.html and http://hippo.ornl.gov/ (NOAA, 2009; NASA, 2009; CDIAC, 2012).

Emissions data used in the modeling are available upon request at http://eclipse.nilu.no/ (NILU, 2013). For model data, please contact Marianne T. Lund (m.t.lund@ cicero.oslo.no).

\section{The Supplement related to this article is available online at doi:10.5194/acp-17-6003-2017-supplement.}

Competing interests. The authors declare that they have no conflict of interest.

Acknowledgements. This work was funded by the Research Council of Norway through the projects TEMPO, SLAC, AC/BC and QUISARC. We also acknowledge the Reseach Council of Norway's programme for supercomputing (NOTUR). We thank Yutaka Kondo, University of Tokyo, for providing results from the A-FORCE flight campaign.

Edited by: T. Takemura

Reviewed by: three anonymous referees

\section{References}

Allen, R. J. and Landuyt, W.: The vertical distribution of black carbon in CMIP5 models: Comparison to observations and the importance of convective transport, J. Geophys. Res.-Atmos., 119, 4808-4835, doi:10.1002/2014JD021595, 2014.

AMAP: AMAP Assessment 2015: Black carbon and ozone as Arctic climate forcers, Arctic Monitoring and Assessment Programme (AMAP), Oslo, Norway, 2015. 
Anenberg, S. C., Schwartz, J., Shindell, D., Amann, M., Faluvegi, G., Klimont, Z., Janssens-Maenhout, G., Pozzoli, L., Van Dingenen, R., Vignati, E., Emberson, L., Muller, N. Z., West, J. J., Williams, M., Demkine, V., Hicks, W. K., Kuylenstierna, J., Raes, F., and Ramanathan, V.: Global Air Quality and Health Co-benefits of Mitigating Near-Term Climate Change through Methane and Black Carbon Emission Controls, Environ. Health Persp., 120, 831-839, doi:10.1289/ehp.1104301, 2012.

Aunan, K., Fang, J., Hu, T., Seip, H. M., and Vennemo, H.: Climate Change and Air Quality - Measures with Co-Benefits in China, Environ. Sci. Technol., 40, 4822-4829, doi:10.1021/es062994k, 2006.

Balkanski, Y., Myhre, G., Gauss, M., Rädel, G., Highwood, E. J., and Shine, K. P.: Direct radiative effect of aerosols emitted by transport: from road, shipping and aviation, Atmos. Chem. Phys., 10, 4477-4489, doi:10.5194/acp-10-4477-2010, 2010.

Ban-Weiss, G., Cao, L., Bala, G., and Caldeira, K.: Dependence of climate forcing and response on the altitude of black carbon aerosols, Clim. Dynam., 6, 034032, doi:10.1007/s00382011-1052-y, 2011.

Bauer, S. E., Koch, D., Unger, N., Metzger, S. M., Shindell, D. T., and Streets, D. G.: Nitrate aerosols today and in 2030: a global simulation including aerosols and tropospheric ozone, Atmos. Chem. Phys., 7, 5043-5059, doi:10.5194/acp-7-5043-2007, 2007.

Bellouin, N., Rae, J., Jones, A., Johnson, C., Haywood, J., and Boucher, O.: Aerosol forcing in the Climate Model Intercomparison Project (CMIP5) simulations by HadGEM2-ES and the role of ammonium nitrate, J. Geophys. Res.-Atmos., 116, D20206, doi:10.1029/2011jd016074, 2011.

Berge, E.: Coupling of wet scavenging of sulphur to clouds in a numerical weather prediction model, Tellus B, 45, 1-22, doi:10.1034/j.1600-0889.1993.00001.x, 1993.

Berglen, T. F., Berntsen, T. K., Isaksen, I. S. A., and Sundet, J. K.: A global model of the coupled sulfur/oxidant chemistry in the troposphere: The sulfur cycle, J. Geophys. Res.-Atmos., 109, D19310, doi:10.1029/2003jd003948, 2004.

Berntsen, T., Fuglestvedt, J., Myhre, G., Stordal, F., and Berglen, T. F.: Abatement of greenhouse gases: Does location matter?, Climatic Change, 74, 377-411, doi:10.1007/s10584-006-04334, 2006.

Berntsen, T. K. and Isaksen, I. S. A.: A global three-dimensional chemical transport model for the troposphere 1. Model description and CO and ozone results, J. Geophys. Res.-Atmos., 102, 21239-21280, doi:10.1029/97jd01140, 1997.

Bollasina, M. A., Ming, Y., Ramaswamy, V., Schwarzkopf, M. D., and Naik, V.: Contribution of local and remote anthropogenic aerosols to the twentieth century weakening of the South Asian Monsoon, Geophys. Res. Lett., 41, 680-687, doi:10.1002/2013GL058183, 2014.

Bond, T. C. and Bergstrom, R. W.: Light absorption by carbonaceous particles: An investigative review, Aerosol Sci. Tech., 40, 27-67, doi:10.1080/02786820500421521, 2006.

Bond, T. C., Doherty, S. J., Fahey, D. W., Forster, P. M., Berntsen, T., DeAngelo, B. J., Flanner, M. G., Ghan, S., Kärcher, B., Koch, D., Kinne, S., Kondo, Y., Quinn, P. K., Sarofim, M. C., Schultz, M. G., Schulz, M., Venkataraman, C., Zhang, H., Zhang, S., Bellouin, N., Guttikunda, S. K., Hopke, P. K., Jacobson, M. Z., Kaiser, J. W., Klimont, Z., Lohmann, U., Schwarz, J. P.,
Shindell, D., Storelvmo, T., Warren, S. G., and Zender, C. S.: Bounding the role of black carbon in the climate system: A scientific assessment, J. Geophys. Res.-Atmos., 118, 5380-5552, doi:10.1002/jgrd.50171, 2013.

Boucher, O., Randall, D., Artaxo, P., Bretherton, C., Feingold, G., Forster, P., Kerminen, V.-M., Kondo, Y., Liao, H., Lohmann, U., Rasch, P., Satheesh, S. K., Sherwood, S., Stevens, B., and Zhang, X. Y.: Clouds and Aerosols, in: Climate Change 2013: The Physical Science Basis. Contribution of Working Group I to the Fifth Assessment Report of the Intergovernmental Panel on Climate Change, edited by: Stocker, T. F., Qin, D., Plattner, G.-K., Tignor, M., Allen, S. K., Boschung, J., Nauels, A., Xia, Y., Bex, V., and Midgley, P. M., Cambridge University Press, Cambridge, UK and New York, NY, USA, 2013.

Bourgeois, Q. and Bey, I.: Pollution transport efficiency toward the Arctic: Sensitivity to aerosol scavenging and source regions, J. Geophys. Res.-Atmos., 116, D08213, doi:10.1029/2010JD015096, 2011.

Bouwman, A. F., Lee, D. S., Asman, W. A. H., Dentener, F. J., Van Der Hoek, K. W., and Olivier, J. G. J.: A global high-resolution emission inventory for ammonia, Global Biogeochem. Cy., 11, 561-587, doi:10.1029/97GB02266, 1997.

Bowerman, N. H. A., Frame, D. J., Huntingford, C., Lowe, J. A., Smith, S. M., and Allen, M. R.: The role of short-lived climate pollutants in meeting temperature goals, Nature Clim. Change, 3, 1021-1024, doi:10.1038/nclimate2034, 2013.

Breider, T. J., Mickley, L. J., Jacob, D. J., Wang, Q., Fisher, J. A., Chang, R. Y. W., and Alexander, B.: Annual distributions and sources of Arctic aerosol components, aerosol optical depth, and aerosol absorption, J. Geophys. Res.-Atmos., 119, 4107-4124, doi:10.1002/2013JD020996, 2014.

Brock, C. A., Cozic, J., Bahreini, R., Froyd, K. D., Middlebrook, A. M., McComiskey, A., Brioude, J., Cooper, O. R., Stohl, A., Aikin, K. C., de Gouw, J. A., Fahey, D. W., Ferrare, R. A., Gao, R.-S., Gore, W., Holloway, J. S., Hübler, G., Jefferson, A., Lack, D. A., Lance, S., Moore, R. H., Murphy, D. M., Nenes, A., Novelli, P. C., Nowak, J. B., Ogren, J. A., Peischl, J., Pierce, R. B., Pilewskie, P., Quinn, P. K., Ryerson, T. B., Schmidt, K. S., Schwarz, J. P., Sodemann, H., Spackman, J. R., Stark, H., Thomson, D. S., Thornberry, T., Veres, P., Watts, L. A., Warneke, C., and Wollny, A. G.: Characteristics, sources, and transport of aerosols measured in spring 2008 during the aerosol, radiation, and cloud processes affecting Arctic Climate (ARCPAC) Project, Atmos. Chem. Phys., 11, 2423-2453, doi:10.5194/acp-11-24232011, 2011.

Browse, J., Carslaw, K. S., Arnold, S. R., Pringle, K., and Boucher, O.: The scavenging processes controlling the seasonal cycle in Arctic sulphate and black carbon aerosol, Atmos. Chem. Phys., 12, 6775-6798, doi:10.5194/acp-12-6775-2012, 2012.

CDIAC - Carbon Dioxide Information Analysis Center Data Archive, Oak Ridge National Laboratory: HIPPO, available at: http://hippo.ornl.gov/ (last access: September 2013), 2012.

Cozic, J., Verheggen, B., Mertes, S., Connolly, P., Bower, K., Petzold, A., Baltensperger, U., and Weingartner, E.: Scavenging of black carbon in mixed phase clouds at the high alpine site Jungfraujoch, Atmos. Chem. Phys., 7, 1797-1807, doi:10.5194/acp-7-1797-2007, 2007.

Doherty, S. J., Warren, S. G., Grenfell, T. C., Clarke, A. D., and Brandt, R. E.: Light-absorbing impurities in Arctic snow, 
Atmos. Chem. Phys., 10, 11647-11680, doi:10.5194/acp-1011647-2010, 2010

Eckhardt, S., Quennehen, B., Olivié, D. J. L., Berntsen, T. K., Cherian, R., Christensen, J. H., Collins, W., Crepinsek, S., Daskalakis, N., Flanner, M., Herber, A., Heyes, C., Hodnebrog, Ø., Huang, L., Kanakidou, M., Klimont, Z., Langner, J., Law, K. S., Lund, M. T., Mahmood, R., Massling, A., Myriokefalitakis, S., Nielsen, I. E., Nøjgaard, J. K., Quaas, J., Quinn, P. K., Raut, J.-C., Rumbold, S. T., Schulz, M., Sharma, S., Skeie, R. B., Skov, H., Uttal, T., von Salzen, K., and Stohl, A.: Current model capabilities for simulating black carbon and sulfate concentrations in the Arctic atmosphere: a multi-model evaluation using a comprehensive measurement data set, Atmos. Chem. Phys., 15, 9413-9433, doi:10.5194/acp-15-9413-2015, 2015.

Ekman, A. M. L., Wang, C., Strom, J., and Krejci, R.: Explicit simulation of aerosol physics in a cloud-resolving model: Aerosol transport and processing in the free troposphere, J. Atmos. Sci., 63, 682-696, doi:10.1175/jas3645.1, 2006.

Emmons, L. K., Arnold, S. R., Monks, S. A., Huijnen, V., Tilmes, S., Law, K. S., Thomas, J. L., Raut, J.-C., Bouarar, I., Turquety, S., Long, Y., Duncan, B., Steenrod, S., Strode, S., Flemming, J., Mao, J., Langner, J., Thompson, A. M., Tarasick, D., Apel, E. C., Blake, D. R., Cohen, R. C., Dibb, J., Diskin, G. S., Fried, A., Hall, S. R., Huey, L. G., Weinheimer, A. J., Wisthaler, A., Mikoviny, T., Nowak, J., Peischl, J., Roberts, J. M., Ryerson, T., Warneke, C., and Helmig, D.: The POLARCAT Model Intercomparison Project (POLMIP): overview and evaluation with observations, Atmos. Chem. Phys., 15, 6721-6744, doi:10.5194/acp15-6721-2015, 2015.

EPA: Report to Congress on black carbon. US Environmental Protection Agency, Washington DC, USA, 2012.

Fan, S. M., Schwarz, J. P., Liu, J., Fahey, D. W., Ginoux, P., Horowitz, L. W., Levy, H., Ming, Y., and Spackman, J. R.: Inferring ice formation processes from global-scale black carbon profiles observed in the remote atmosphere and model simulations, J. Geophys. Res.-Atmos., 117, D23205, doi:10.1029/2012JD018126, 2012.

FED, Colorado State University's Cooperative Institute for Research in the Atmosphere: IMPROVE, available at: http: //views.cira.colostate.edu/fed/DataWizard/Default.aspx, last access: September 2013.

Flanner, M. G.: Arctic climate sensitivity to local black carbon, J. Geophys. Res.-Atmos., 118, 1840-1851, doi:10.1002/jgrd.50176, 2013.

Flanner, M. G., Zender, C. S., Hess, P. G., Mahowald, N. M., Painter, T. H., Ramanathan, V., and Rasch, P. J.: Springtime warming and reduced snow cover from carbonaceous particles, Atmos. Chem. Phys., 9, 2481-2497, doi:10.5194/acp-9-24812009, 2009.

Fujino, J., Nair, R., Kainuma, M., Masui, T., and Matsuoka, Y.: Multi-gas mitigation analysis on stabilization scenarios using AIM global model, Special issue, Energ. J., 3, 343-353, 2006.

Gong, X., Zhang, C., Chen, H., Nizkorodov, S. A., Chen, J., and Yang, X.: Size distribution and mixing state of black carbon particles during a heavy air pollution episode in Shanghai, Atmos. Chem. Phys., 16, 5399-5411, doi:10.5194/acp-16-53992016, 2016.
Grieshop, A. P., Reynolds, C. C. O., Kandlikar, M., and Dowlatabadi, H.: A black-carbon mitigation wedge, Nat. Geosci., 2, 533-534, doi:10.1038/ngeo595, 2009.

Guenther, A. B., Jiang, X., Heald, C. L., Sakulyanontvittaya, T., Duhl, T., Emmons, L. K., and Wang, X.: The Model of Emissions of Gases and Aerosols from Nature version 2.1 (MEGAN2.1): an extended and updated framework for modeling biogenic emissions, Geosci. Model Dev., 5, 1471-1492, doi:10.5194/gmd-51471-2012, 2012.

He, C., Li, Q., Liou, K.-N., Qi, L., Tao, S., and Schwarz, J. P.: Microphysics-based black carbon aging in a global CTM: constraints from HIPPO observations and implications for global black carbon budget, Atmos. Chem. Phys., 16, 3077-3098, doi:10.5194/acp-16-3077-2016, 2016.

Hijioka, J., Matsuoka, Y., Nishimoto, H., Masui, M., and Kainuma, M.: Global GHG emissions scenarios under GHG concentration stabilization targets, Journal of Global Environmental Engineering, 13, 97-108, 2008.

Hodnebrog, Ø., Myhre, G., and Samset, B. H.: How shorter black carbon lifetime alters its climate effect, Nat Commun., 5, 5065, doi:10.1038/ncomms6065, 2014.

Hoose, C., Kristjansson, J. E., Chen, J. P., and Hazra, A.: A Classical-Theory-Based Parameterization of Heterogeneous Ice Nucleation by Mineral Dust, Soot, and Biological Particles in a Global Climate Model, J. Atmos. Sci., 67, 2483-2503, doi:10.1175/2010jas3425.1, 2010.

Huang, K., Fu, J. S., Prikhodko, V. Y., Storey, J. M., Romanov, A., Hodson, E. L., Cresko, J., Morozova, I., Ignatieva, Y., and Cabaniss, J.: Russian anthropogenic black carbon: Emission reconstruction and Arctic black carbon simulation, J. Geophys. Res. Atmos., 120, 11306-11333, doi:10.1002/2015JD023358, 2015.

Jacob, D. J., Crawford, J. H., Maring, H., Clarke, A. D., Dibb, J. E., Emmons, L. K., Ferrare, R. A., Hostetler, C. A., Russell, P. B., Singh, H. B., Thompson, A. M., Shaw, G. E., McCauley, E., Pederson, J. R., and Fisher, J. A.: The Arctic Research of the Composition of the Troposphere from Aircraft and Satellites (ARCTAS) mission: design, execution, and first results, Atmos. Chem. Phys., 10, 5191-5212, doi:10.5194/acp-10-5191-2010, 2010.

Kajino, M., Inomata, Y., Sato, K., Ueda, H., Han, Z., An, J., Katata, G., Deushi, M., Maki, T., Oshima, N., Kurokawa, J., Ohara, T., Takami, A., and Hatakeyama, S.: Development of the RAQM2 aerosol chemical transport model and predictions of the Northeast Asian aerosol mass, size, chemistry, and mixing type, Atmos. Chem. Phys., 12, 11833-11856, doi:10.5194/acp12-11833-2012, 2012.

Kipling, Z., Stier, P., Schwarz, J. P., Perring, A. E., Spackman, J. R., Mann, G. W., Johnson, C. E., and Telford, P. J.: Constraints on aerosol processes in climate models from vertically-resolved aircraft observations of black carbon, Atmos. Chem. Phys., 13, 5969-5986, doi:10.5194/acp-13-5969-2013, 2013.

Kipling, Z., Stier, P., Johnson, C. E., Mann, G. W., Bellouin, N., Bauer, S. E., Bergman, T., Chin, M., Diehl, T., Ghan, S. J., Iversen, T., Kirkevåg, A., Kokkola, H., Liu, X., Luo, G., van Noije, T., Pringle, K. J., von Salzen, K., Schulz, M., Seland, Ø., Skeie, R. B., Takemura, T., Tsigaridis, K., and Zhang, K.: What controls the vertical distribution of aerosol? Relationships between process sensitivity in HadGEM3-UKCA and inter-model variation from AeroCom Phase II, Atmos. Chem. Phys., 16, 2221-2241, doi:10.5194/acp-16-2221-2016, 2016. 
Klimont, Z., Kupiainen, K., Heyes, C., Purohit, P., Cofala, J., Rafaj, P., Borken-Kleefeld, J., and Schöpp, W.: Global anthropogenic emissions of particulate matter including black carbon, Atmos. Chem. Phys. Discuss., doi:10.5194/acp-2016-880, in review, 2016

Koch, D. and Del Genio, A. D.: Black carbon semi-direct effects on cloud cover: review and synthesis, Atmos. Chem. Phys., 10, 7685-7696, doi:10.5194/acp-10-7685-2010, 2010.

Koch, D., Menon, S., Del Genio, A., Ruedy, R., Alienov, I., and Schmidt, G. A.: Distinguishing Aerosol Impacts on Climate over the Past Century, J. Climate, 22, 2659-2677, doi:10.1175/2008jcli2573.1, 2009a.

Koch, D., Schulz, M., Kinne, S., McNaughton, C., Spackman, J. R., Balkanski, Y., Bauer, S., Berntsen, T., Bond, T. C., Boucher, O., Chin, M., Clarke, A., De Luca, N., Dentener, F., Diehl, T., Dubovik, O., Easter, R., Fahey, D. W., Feichter, J., Fillmore, D., Freitag, S., Ghan, S., Ginoux, P., Gong, S., Horowitz, L., Iversen, T., Kirkevåg, A., Klimont, Z., Kondo, Y., Krol, M., Liu, X., Miller, R., Montanaro, V., Moteki, N., Myhre, G., Penner, J. E., Perlwitz, J., Pitari, G., Reddy, S., Sahu, L., Sakamoto, H., Schuster, G., Schwarz, J. P., Seland, Ø., Stier, P., Takegawa, N., Takemura, T., Textor, C., van Aardenne, J. A., and Zhao, Y.: Evaluation of black carbon estimations in global aerosol models, Atmos. Chem. Phys., 9, 9001-9026, doi:10.5194/acp-9-9001-2009, 2009b.

Koehler, K. A., DeMott, P. J., Kreidenweis, S. M., Popovicheva, O. B., Petters, M. D., Carrico, C. M., Kireeva, E. D., Khokhlova, T. D., and Shonija, N. K.: Cloud condensation nuclei and ice nucleation activity of hydrophobic and hydrophilic soot particles, Phys. Chem. Chem. Phys., 11, 79067920, doi:10.1039/b905334b, 2009.

Kopp, R. E. and Mauzerall, D. L.: Assessing the climatic benefits of black carbon mitigation, P. Natl. Acad. Sci. USA, 107, 1170311708, doi:10.1073/pnas.0909605107, 2010.

Lee, Y. H., Lamarque, J.-F., Flanner, M. G., Jiao, C., Shindell, D. T., Berntsen, T., Bisiaux, M. M., Cao, J., Collins, W. J., Curran, M., Edwards, R., Faluvegi, G., Ghan, S., Horowitz, L. W., McConnell, J. R., Ming, J., Myhre, G., Nagashima, T., Naik, V., Rumbold, S. T., Skeie, R. B., Sudo, K., Takemura, T., Thevenon, F., Xu, B., and Yoon, J.-H.: Evaluation of preindustrial to presentday black carbon and its albedo forcing from Atmospheric Chemistry and Climate Model Intercomparison Project (ACCMIP), Atmos. Chem. Phys., 13, 2607-2634, doi:10.5194/acp13-2607-2013, 2013.

Liu, J., Fan, S., Horowitz, L. W., and Levy II, H.: Evaluation of factors controlling long-range transport of black carbon to the Arctic, J. Geophys. Res.-Atmos., 116, D04307, doi:10.1029/2010jd015145, 2011.

Lohmann, U. and Feichter, J.: Global indirect aerosol effects: a review, Atmos. Chem. Phys., 5, 715-737, doi:10.5194/acp-5-7152005, 2005.

Lund, M. T. and Berntsen, T.: Parameterization of black carbon aging in the OsloCTM2 and implications for regional transport to the Arctic, Atmos. Chem. Phys., 12, 6999-7014, doi:10.5194/acp-12-6999-2012, 2012.

Lund, M. T., Berntsen, T. K., Heyes, C., Klimont, Z., and Samset, B. H.: Global and regional climate impacts of black carbon and coemitted species from the on-road diesel sector, Atmos. Environ., 98, 50-58, doi:10.1016/j.atmosenv.2014.08.033, 2014.
Mahmood, R., von Salzen, K., Flanner, M., Sand, M., Langner, J., Wang, H., and Huang, L.: Seasonality of global and Arctic black carbon processes in the Arctic Monitoring and Assessment Programme models, J. Geophys. Res.-Atmos., 121, 7100-7116, doi:10.1002/2016JD024849, 2016.

Makkonen, R., Romakkaniemi, S., Kokkola, H., Stier, P., Räisänen, P., Rast, S., Feichter, J., Kulmala, M., and Laaksonen, A. Brightening of the global cloud field by nitric acid and the associated radiative forcing, Atmos. Chem. Phys., 12, 7625-7633, doi:10.5194/acp-12-7625-2012, 2012.

Mann, G. W., Carslaw, K. S., Spracklen, D. V., Ridley, D. A., Manktelow, P. T., Chipperfield, M. P., Pickering, S. J., and Johnson, C. E.: Description and evaluation of GLOMAP-mode: a modal global aerosol microphysics model for the UKCA composition-climate model, Geosci. Model Dev., 3, 519-551, doi:10.5194/gmd-3-519-2010, 2010.

McMeeking, G. R., Morgan, W. T., Flynn, M., Highwood, E. J., Turnbull, K., Haywood, J., and Coe, H.: Black carbon aerosol mixing state, organic aerosols and aerosol optical properties over the United Kingdom, Atmos. Chem. Phys., 11, 9037-9052, doi:10.5194/acp-11-9037-2011, 2011.

Metzger, S., Dentener, F., Krol, M., Jeuken, A., and Lelieveld, J.: Gas/aerosol partitioning - 2. Global modeling results, J. Geophys. Res.-Atmos., 107, 4313, doi:10.1029/2001jd001103, 2002a.

Metzger, S., Dentener, F., Pandis, S., and Lelieveld, J.: Gas/aerosol partitioning: 1. A computationally efficient model, J. Geophys. Res.-Atmos., 107, 4312, doi:10.1029/2001jd001102, 2002 b.

Monks, S. A., Arnold, S. R., Emmons, L. K., Law, K. S., Turquety, S., Duncan, B. N., Flemming, J., Huijnen, V., Tilmes, S., Langner, J., Mao, J., Long, Y., Thomas, J. L., Steenrod, S. D., Raut, J. C., Wilson, C., Chipperfield, M. P., Diskin, G. S., Weinheimer, A., Schlager, H., and Ancellet, G.: Multi-model study of chemical and physical controls on transport of anthropogenic and biomass burning pollution to the Arctic, Atmos. Chem. Phys., 15, 3575-3603, doi:10.5194/acp-15-3575-2015, 2015.

Moteki, N., Kondo, Y., Miyazaki, Y., Takegawa, N., Komazaki, Y., Kurata, G., Shirai, T., Blake, D. R., Miyakawa, T., and Koike, M.: Evolution of mixing state of black carbon particles: Aircraft measurements over the western Pacific in March 2004, Geophys. Res. Lett., 34, L11803, doi:10.1029/2006g1028943, 2007.

Myhre, G., Grini, A., and Metzger, S.: Modelling of nitrate and ammonium-containing aerosols in presence of sea salt, Atmos. Chem. Phys., 6, 4809-4821, doi:10.5194/acp-6-4809-2006, 2006.

Myhre, G., Samset, B. H., Schulz, M., Balkanski, Y., Bauer, S., Berntsen, T. K., Bian, H., Bellouin, N., Chin, M., Diehl, T., Easter, R. C., Feichter, J., Ghan, S. J., Hauglustaine, D., Iversen, T., Kinne, S., Kirkevåg, A., Lamarque, J.-F., Lin, G., Liu, X., Lund, M. T., Luo, G., Ma, X., van Noije, T., Penner, J. E., Rasch, P. J., Ruiz, A., Seland, Ø., Skeie, R. B., Stier, P., Takemura, T., Tsigaridis, K., Wang, P., Wang, Z., Xu, L., Yu, H., Yu, F., Yoon, J.-H., Zhang, K., Zhang, H., and Zhou, C.: Radiative forcing of the direct aerosol effect from AeroCom Phase II simulations, Atmos. Chem. Phys., 13, 1853-1877, doi:10.5194/acp-13-18532013, 2013.

NASA: ARCTAS, available at:https://www-air.larc.nasa.gov/ missions/arctas/arctas.html (last access: August 2013), 2009. 
NOAA: ARCPAC, available at: http://www.esrl.noaa.gov/csd/ projects/arcpac/ (last access: November 2012), 2009.

NOAA: NOAA/GMD, available at: https://www.esrl.noaa.gov/ gmd/, last access: August 2013.

NILU - Norwegian Institute for Air Research: ECLIPSEv4, available at: http://eclipse.nilu.no/ (last access: May 2017), 2013.

NILU - Norwegian Institute for Air Research: EBAS, available at: http://ebas.nilu.no/, last access: July 2015.

Oshima, N., Kondo, Y., Moteki, N., Takegawa, N., Koike, M., Kita, K., Matsui, H., Kajino, M., Nakamura, H., Jung, J. S., and Kim, Y. J.: Wet removal of black carbon in Asian outflow: Aerosol Radiative Forcing in East Asia (A-FORCE) aircraft campaign, J. Geophys. Res.-Atmos., 117, D03204, doi:10.1029/2011jd016552, 2012.

Park, R. J., Jacob, D. J., Palmer, P. I., Clarke, A. D., Weber, R. J., Zondlo, M. A., Eisele, F. L., Bandy, A. R., Thornton, D. C., Sachse, G. W., and Bond, T. C.: Export efficiency of black carbon aerosol in continental outflow: Global implications, J. Geophys. Res.-Atmos., 110, D11205, doi:10.1029/2004jd005432, 2005.

Petters, M. D. and Kreidenweis, S. M.: A single parameter representation of hygroscopic growth and cloud condensation nucleus activity, Atmos. Chem. Phys., 7, 1961-1971, doi:10.5194/acp-71961-2007, 2007.

Petzold, A., Ogren, J. A., Fiebig, M., Laj, P., Li, S.-M., Baltensperger, U., Holzer-Popp, T., Kinne, S., Pappalardo, G., Sugimoto, N., Wehrli, C., Wiedensohler, A., and Zhang, X.-Y.: Recommendations for reporting "black carbon" measurements, Atmos. Chem. Phys., 13, 8365-8379, doi:10.5194/acp-13-83652013, 2013.

Popovicheva, O. B., Persiantseva, N. M., Tishkova, V., Shonija, N. K., and Zubareva, N. A.: Quantification of water uptake by soot particles, Environ. Res. Lett., 3, 025009, doi:10.1088/17489326/3/2/025009, 2008.

Popovicheva, O. B., Persiantseva, N. M., Kireeva, E. D., Khokhlova, T. D., and Shonija, N. K.: Quantification of the Hygroscopic Effect of Soot Aging in the Atmosphere: Laboratory Simulations, J. Phys. Chem. A, 115, 298-306, doi:10.1021/jp109238x, 2011.

Pratt, K. A. and Prather, K. A.: Aircraft measurements of vertical profiles of aerosol mixing states, J. Geophys. Res.-Atmos., 115, D11305, doi:10.1029/2009jd013150, 2010.

Pringle, K. J., Tost, H., Message, S., Steil, B., Giannadaki, D., Nenes, A., Fountoukis, C., Stier, P., Vignati, E., and Lelieveld, J.: Description and evaluation of GMXe: a new aerosol submodel for global simulations (v1), Geosci. Model Dev., 3, 391-412, doi:10.5194/gmd-3-391-2010, 2010.

Raatikainen, T., Brus, D., Hyvärinen, A.-P., Svensson, J., Asmi, E., and Lihavainen, H.: Black carbon concentrations and mixing state in the Finnish Arctic, Atmos. Chem. Phys., 15, 1005710070, doi:10.5194/acp-15-10057-2015, 2015.

Samset, B. H. and Myhre, G.: Vertical dependence of black carbon, sulphate and biomass burning aerosol radiative forcing, Geophys. Res. Lett., 38, L24802, doi:10.1029/2011GL049697, 2011.

Samset, B. H. and Myhre, G.: Climate response to externally mixed black carbon as a function of altitude, J. Geophys. Res.-Atmos., 120, 2913-2927, doi:10.1002/2014JD022849, 2015.

Samset, B. H., Myhre, G., Herber, A., Kondo, Y., Li, S.-M., Moteki, N., Koike, M., Oshima, N., Schwarz, J. P., Balkanski, Y., Bauer, S. E., Bellouin, N., Berntsen, T. K., Bian, H., Chin, M., Diehl, T., Easter, R. C., Ghan, S. J., Iversen, T., Kirkevåg, A., Lamar- que, J.-F., Lin, G., Liu, X., Penner, J. E., Schulz, M., Seland, Ø., Skeie, R. B., Stier, P., Takemura, T., Tsigaridis, K., and Zhang, K.: Modelled black carbon radiative forcing and atmospheric lifetime in AeroCom Phase II constrained by aircraft observations, Atmos. Chem. Phys., 14, 12465-12477, doi:10.5194/acp14-12465-2014, 2014.

Sato, Y., Miura, H., Yashiro, H., Goto, D., Takemura, T., Tomita, H., and Nakajima, T.: Unrealistically pristine air in the Arctic produced by current global scale models, Supplement, Sci. Rep., 6, 26561, doi:10.1038/srep26561, 2016.

Schulz, M., Textor, C., Kinne, S., Balkanski, Y., Bauer, S., Berntsen, T., Berglen, T., Boucher, O., Dentener, F., Guibert, S., Isaksen, I. S. A., Iversen, T., Koch, D., Kirkevåg, A., Liu, X., Montanaro, V., Myhre, G., Penner, J. E., Pitari, G., Reddy, S., Seland, $\varnothing$., Stier, P., and Takemura, T.: Radiative forcing by aerosols as derived from the AeroCom present-day and pre-industrial simulations, Atmos. Chem. Phys., 6, 5225-5246, doi:10.5194/acp-65225-2006, 2006.

Schwarz, J. P., Gao, R. S., Spackman, J. R., Watts, L. A., Thomson, D. S., Fahey, D. W., Ryerson, T. B., Peischl, J., Holloway, J. S., Trainer, M., Frost, G. J., Baynard, T., Lack, D. A., de Gouw, J. A., Warneke, C., and Del Negro, L. A.: Measurement of the mixing state, mass, and optical size of individual black carbon particles in urban and biomass burning emissions, Geophys. Res. Lett., 35, L13810, doi:10.1029/2008g1033968, 2008.

Schwarz, J. P., Samset, B. H., Perring, A. E., Spackman, J. R., Gao, R. S., Stier, P., Schulz, M., Moore, F. L., Ray, E. A., and Fahey, D. W.: Global-scale seasonally resolved black carbon vertical profiles over the Pacific, Geophys. Res. Lett., 40, 5542-5547, doi:10.1002/2013GL057775, 2013.

Seinfeld, J. H. and Pandis, S. N.: Atmospheric Chemistry and Physics - From Air Pollution to Climate Change, 2nd edition, John Wiley and Sons, Inc., New York, USA, 1998.

Sharma, S., Ishizawa, M., Chan, D., Lavoué, D., Andrews, E., Eleftheriadis, K., and Maksyutov, S.: 16-year simulation of Arctic black carbon: Transport, source contribution, and sensitivity analysis on deposition, J. Geophys. Res.-Atmos., 118, 943-964, doi:10.1029/2012JD017774, 2013.

Shindell, D., Faluvegi, G., Walsh, M., Anenberg, S. C., Van Dingenen, R., Muller, N. Z., Austin, J., Koch, D., and Milly, G.: Climate, health, agricultural and economic impacts of tighter vehicle-emission standards, Nature Climate Change, 1, 59-66, doi:10.1038/nclimate1066, 2011.

Shindell, D. T., Chin, M., Dentener, F., Doherty, R. M., Faluvegi, G., Fiore, A. M., Hess, P., Koch, D. M., MacKenzie, I. A., Sanderson, M. G., Schultz, M. G., Schulz, M., Stevenson, D. S., Teich, H., Textor, C., Wild, O., Bergmann, D. J., Bey, I., Bian, H., Cuvelier, C., Duncan, B. N., Folberth, G., Horowitz, L. W., Jonson, J., Kaminski, J. W., Marmer, E., Park, R., Pringle, K. J., Schroeder, S., Szopa, S., Takemura, T., Zeng, G., Keating, T. J., and Zuber, A.: A multi-model assessment of pollution transport to the Arctic, Atmos. Chem. Phys., 8, 5353-5372, doi:10.5194/acp-85353-2008, 2008.

Shindell, D. T., Lamarque, J.-F., Schulz, M., Flanner, M., Jiao, C., Chin, M., Young, P. J., Lee, Y. H., Rotstayn, L., Mahowald, N., Milly, G., Faluvegi, G., Balkanski, Y., Collins, W. J., Conley, A. J., Dalsoren, S., Easter, R., Ghan, S., Horowitz, L., Liu, X., Myhre, G., Nagashima, T., Naik, V., Rumbold, S. T., Skeie, R., Sudo, K., Szopa, S., Takemura, T., Voulgarakis, A., Yoon, J.-H., 
and Lo, F.: Radiative forcing in the ACCMIP historical and future climate simulations, Atmos. Chem. Phys., 13, 2939-2974, doi:10.5194/acp-13-2939-2013, 2013.

Shiraiwa, M., Kondo, Y., Moteki, N., Takegawa, N., Miyazaki, Y., and Blake, D. R.: Evolution of mixing state of black carbon in polluted air from Tokyo, Geophys. Res. Lett, 34, L16803, doi:10.1029/2007g1029819, 2007.

Skeie, R. B., Berntsen, T., Myhre, G., Pedersen, C. A., Ström, J., Gerland, S., and Ogren, J. A.: Black carbon in the atmosphere and snow, from pre-industrial times until present, Atmos. Chem. Phys., 11, 6809-6836, doi:10.5194/acp-11-6809-2011, 2011.

Sovde, O. A., Gauss, M., Smyshlyaev, S. P., and Isaksen, I. S. A.: Evaluation of the chemical transport model Oslo CTM2 with focus on arctic winter ozone depletion, J. Geophys. Res.-Atmos., 113, D09304, doi:10.1029/2007jd009240, 2008.

Stjern, C. W., Samset, B. H., Myhre, G., Bian, H., Chin, M., Davila, Y., Dentener, F., Emmons, L., Flemming, J., Haslerud, A. S., Henze, D., Jonson, J. E., Kucsera, T., Lund, M. T., Schulz, M., Sudo, K., Takemura, T., and Tilmes, S.: Global and regional radiative forcing from $20 \%$ reductions in $\mathrm{BC}$, OC and $\mathrm{SO}_{4}-$ an HTAP2 multi-model study, Atmos. Chem. Phys., 16, 1357913599, doi:10.5194/acp-16-13579-2016, 2016.

Stohl, A.: Characteristics of atmospheric transport into the Arctic troposphere, J. Geophys. Res.-Atmos., 111, D11306, doi:10.1029/2005jd006888, 2006.

Stohl, A., Klimont, Z., Eckhardt, S., Kupiainen, K., Shevchenko, V. P., Kopeikin, V. M., and Novigatsky, A. N.: Black carbon in the Arctic: the underestimated role of gas flaring and residential combustion emissions, Atmos. Chem. Phys., 13, 8833-8855, doi:10.5194/acp-13-8833-2013, 2013

Streets, D. G., Bond, T. C., Carmichael, G. R., Fernandes, S. D., Fu, Q., He, D., Klimont, Z., Nelson, S. M., Tsai, N. Y., Wang, M. Q., Woo, J.-H., and Yarber, K. F.: An inventory of gaseous and primary aerosol emissions in Asia in the year 2000, J. Geophys. Res., 108, 8809, doi:10.1029/2002JD003093, 2003.

Textor, C., Schulz, M., Guibert, S., Kinne, S., Balkanski, Y., Bauer, S., Berntsen, T., Berglen, T., Boucher, O., Chin, M., Dentener, F., Diehl, T., Feichter, J., Fillmore, D., Ginoux, P., Gong, S., Grini, A., Hendricks, J., Horowitz, L., Huang, P., Isaksen, I. S. A., Iversen, T., Kloster, S., Koch, D., Kirkevåg, A., Kristjansson, J. E., Krol, M., Lauer, A., Lamarque, J. F., Liu, X., Montanaro, V., Myhre, G., Penner, J. E., Pitari, G., Reddy, M. S., Seland, Ø., Stier, P., Takemura, T., and Tie, X.: The effect of harmonized emissions on aerosol properties in global models an AeroCom experiment, Atmos. Chem. Phys., 7, 4489-4501, doi:10.5194/acp-7-4489-2007, 2007.

Tiedtke, M.: A comprehensive mass flux scheme for cumulus parameterization in large-scale models, Mon. Weather Rev., 117, 1779-1800, doi:10.1175/15200493(1989)117<1779:acmfsf>2.0.co;2, 1989.

UNEP/WMO: Integrated assessment of black carbon and tropospheric ozone, United Nations Environmental Programme, Nairobi, Kenya, and World Meteorological Organization, Geneva, Switzerland, 282 pp., 2011.

U.S. Environmental Protection Agency Clean Air Markets Division: CASTNET, available at: http://www.epa.gov/castnet, last access: November 2013.

van der Werf, G. R., Randerson, J. T., Giglio, L., Collatz, G. J., Mu, M., Kasibhatla, P. S., Morton, D. C., DeFries, R. S., Jin, Y., and van Leeuwen, T. T.: Global fire emissions and the contribution of deforestation, savanna, forest, agricultural, and peat fires (19972009), Atmos. Chem. Phys., 10, 11707-11735, doi:10.5194/acp10-11707-2010, 2010.

Vignati, E., Wilson, J., and Stier, P.: M7: An efficient sizeresolved aerosol microphysics module for large-scale aerosol transport models, J. Geophys. Res.-Atmos., 109, D22202, doi:10.1029/2003jd004485, 2004.

Vignati, E., Karl, M., Krol, M., Wilson, J., Stier, P., and Cavalli, F.: Sources of uncertainties in modelling black carbon at the global scale, Atmos. Chem. Phys., 10, 2595-2611, doi:10.5194/acp-102595-2010, 2010.

Wang, Q., Jacob, D. J., Spackman, J. R., Perring, A. E., Schwarz, J. P., Moteki, N., Marais, E. A., Ge, C., Wang, J., and Barrett, S. R. H.: Global budget and radiative forcing of black carbon aerosol: Constraints from pole-to-pole (HIPPO) observations across the Pacific, J. Geophys. Res.-Atmos., 119, 195-206, doi:10.1002/2013JD020824, 2014.

Wang, T. J., Zhuang, B. L., Li, S., Liu, J., Xie, M., Yin, C. Q., Zhang, Y., Yuan, C., Zhu, J. L., Ji, L. Q., and Han, Y.: The interactions between anthropogenic aerosols and the East Asian summer monsoon using RegCCMS, J. Geophys. Res.-Atmos., 120, 5602-5621, doi:10.1002/2014JD022877, 2015.

Wang, X., Doherty, S. J., and Huang, J.: Black carbon and other light-absorbing impurities in snow across Northern China, J. Geophys. Res.-Atmos., 118, 1471-1492, doi:10.1029/2012jd018291, 2013.

Warneke, C., Bahreini, R., Brioude, J., Brock, C. A., de Gouw, J. A., Fahey, D. W., Froyd, K. D., Holloway, J. S., Middlebrook, A., Miller, L., Montzka, S., Murphy, D. M., Peischl, J., Ryerson, T. B., Schwarz, J. P., Spackman, J. R., and Veres, P.: Biomass burning in Siberia and Kazakhstan as an important source for haze over the Alaskan Arctic in April 2008, Geophys. Res. Lett. 36, L02813, doi:10.1029/2008g1036194, 2009.

Warren, S. G. and Wiscombe, W. J.: A model for the spectral albedo of snow. II: Snow containing atmospheric aerosols, J. Atmos. Sci., 37, 2734-2745, 1980.

Wesely, M. L.: Parameterization of surface resistances to gaseous dry deposition in regional-scale numerical models, Atmos. Environ., 23, 1293-1304, doi:10.1016/0004-6981(89)90153-4, 1989.

Wiedinmyer, C., Yokelson, R. J., and Gullett, B. K.: Global Emissions of Trace Gases, Particulate Matter, and Hazardous Air Pollutants from Open Burning of Domestic Waste, Environ. Sci. Technol., 48, 9523-9530, doi:10.1021/es502250z, 2014.

Wofsy, S. C., the HIPPO Science Team, and Cooperating Modellers and Satellite Teams: HIAPER Pole-to-Pole Observations (HIPPO): fine-grained, global-scale measurements of climatically important atmospheric gases and aerosols, Philos. T. R Soc. A, 369, 2073-2086, doi:10.1098/rsta.2010.0313, 2011.

Ye, H., Zhang, R., Shi, J., Huang, J., Warren, S. G., and $\mathrm{Fu}, \mathrm{Q} .:$ Black carbon in seasonal snow across northern Xinjiang in northwestern China, Environ. Res. Lett., 7, 044002, doi:10.1088/1748-9326/7/4/044002, 2012.

Zhang, Q., Jimenez, J. L., Canagaratna, M. R., Allan, J. D., Coe, H., Ulbrich, I., Alfarra, M. R., Takami, A., Middlebrook, A. M., Sun, Y. L., Dzepina, K., Dunlea, E., Docherty, K., DeCarlo, P. F., Salcedo, D., Onasch, T., Jayne, J. T., Miyoshi, T., Shimono, A., Hatakeyama, S., Takegawa, N., Kondo, Y., Schneider, J., Drewnick, F., Borrmann, S., Weimer, S., Demer- 
jian, K., Williams, P., Bower, K., Bahreini, R., Cottrell, L., Griffin, R. J., Rautiainen, J., Sun, J. Y., Zhang, Y. M., and Worsnop, D. R.: Ubiquity and dominance of oxygenated species in organic aerosols in anthropogenically-influenced Northern Hemisphere midlatitudes, Geophys. Res. Lett., 34, L13801, doi:10.1029/2007g1029979, 2007.
Zhang, X. Y., Wang, Y. Q., Niu, T., Zhang, X. C., Gong, S. L., Zhang, Y. M., and Sun, J. Y.: Atmospheric aerosol compositions in China: spatial/temporal variability, chemical signature, regional haze distribution and comparisons with global aerosols, Atmos. Chem. Phys., 12, 779-799, doi:10.5194/acp12-779-2012, 2012. 